\title{
Ethiopia: Intellectual Genocide in the making? The Strong and Pervasive Evidence of Ethnic Inequalities
}

\author{
Girma Berhanu \\ Department of Education and Special Education \\ University of Gothenburg \\ Göteborg, Sweden
}

\begin{abstract}
Ethnic inequalities in all sectors of life in Ethiopia have increasingly become serious and pervasive. Access to higher education (including scholarship grants) and most sought after disciplines appear to be disproportionally distributed along the multitude of ethnic groups in the country. In this paper I argue that intellectual genocide is in the making in three different forms: (1) systematic discrimination against certain groups with regard to educational opportunities, higher education, and scholarship grants; (2) brain drain - the movement of intellectuals and young skilled Ethiopians that has increased under the Tigrean People's Liberation Fronts (TPLF) regime. Some observers say that Ethiopia has become a substantial net exporter of academic talent, a so-called brain drain; (3) cultural genocide, the action of the system which has the aim or effect of dispossessing the people of their lands, territories or resources, cultural values, language, and historical/religious relics and heritages. The philosophical foundation/methodology that undergirds this study is critical theory with elements of poststructuralism and post colonialism. The strategies used to collate and collect data is meta-analysis (data synthesis), some form of discourse analysis, personal accounts, and a limited amount of sociological introspection. There are a number of reasons or mechanisms that lead from ethnicity to violence. My evidence shows that there are already some patterns and discourses that might precipitate or crystallize the mechanisms in Ethiopia. The study shows that it is high time to stop the madness and redress the chronic and pervasive disparities within and between groups. It is an imperative that we focus on our similarities and common destiny. "The fight is never about grapes or lettuce. It is always about people." It is about Ethiopian people. It is just unacceptable to seek self-aggrandizement for ourselves-or for our specific ethnic group, and increase power and influence to draw attention to own importance-and forget about progress and prosperity for the multitudes of ethnic groups in Ethiopia. Our ambitions must be broad enough to include the aspirations and needs of others, for their sakes and for our own.
\end{abstract}

"The caterpillar does all the work, but the butterfly gets all the publicity."

- George Carlin

\section{THE CONTEXT: SETTING THE AGENDA}

Ethiopia is by all accounts a troubled country. The potential for explosion which is primarily ethnic based but also of a class nature is unmistakable/apparent as manifested in recent nationwide protests. The peaceful protests are for now brutally crashed down. Killings and mass imprisonments are rampant. A large amount of research literature and personal accounts testifies to the fact that the source of the problem lies squarely with the Tigrean People's Liberation Fronts (TPLF) ${ }^{1}$. authoritarian rule, the policy of ethnic federalism/ethnic apartheid and divide and rule strategy. The country has gravely and successively stumbled into a brutal form of authoritarianism and human rights violations according to International observers including Human Rights Watch and The European Union. Currently the country is in a military 
siege, under a state of emergency (see also The End of Democracy? Curtailing Political and Civil Rights in Ethiopia by Aalen \& Tronvoll, 200922. ; Arriola and Terrence, 20163.). Although the situation looks calm from the outside as a result of the military actions, a return to peace is unlikely, fragile, and partial at best. Rene Lefort, a recognized East Africa specialist, says (In Al Arabia English, 2016) "the basis of bad governance and authoritarianism that hampers Ethiopia's institutional development is to be found in the persistence of a culture and power system inherited from Abyssinian history. The country is characterized by a ruthless hierarchy and monolithic centralism in the hands of an elite: the Northerner Tigray ethnic group. In the absence of counter-powers, and amid strong growth whose benefits do not trickle down to the rest of the population, the state apparatus is plagued by corruption and impunity. Ethiopia is thus both a rising power in Africa, and a country on the verge of explosion and ethnic conflict." 4 .

A Western diplomat interviewed by the Financial Times reiterated that "They [the rulers] only talk to themselves and their echo-chamber is very loud but it's soundproofed on the outside so they only hear their own propaganda." Analysts say the regime's development model, the foundation of its legitimacy, is becoming its Achilles heel. It is founded on copying nations such as South Korea, Singapore, and China, which prioritised state-led development over democracy and until last year it proved extremely successful ${ }^{5}$.

A prosperous local businessman in Gondor city, interviewed by William Davison of The Guardian said "We don't feel like it is our country. We feel like it is the time when the Italians invaded. We are like second-class citizens." Like all interviewees, he requested anonymity due to fear of reprisals from the authorities. Europeans never colonized Ethiopia, but Mussolini's army occupied the country from 1936 to 1941. Gondor, a city in Ethiopian Northern high lands, Amhara region, [the site of recent and ongoing violent confrontations between civilian protesters and government troops which captured the attention of the world] is still defiant and boldly challenging the heavily armed government troops. Gondar's predicament is a microcosm of Ethiopia's: a toxic brew of uneven development, polarized debate amid a virtual media vacuum, contested history, ethnic tensions, a fragmented opposition, and an authoritarian government. Ethiopia's rulers show few signs of being able to solve the morass of problems, which many believe the government itself caused 6 . The phenomenon has been documented years ago by international scholars in the aftermath of the 2005 election (e.g.; Abbink, 20117.; Clapham, 20098.; Aalen \& Tronvoll, 2009; Arriola, 20139.).

Ethiopia is ranked $17^{\text {th }}$ among the 31 unhealthiest, unhappiest, poorest, and most unsafe countries in the world. Every year, the Legatum Institute, a London-based think tank, releases its annual Prosperity Index. The index ranks 142 countries in terms of their so-called prosperity. Ethiopia scored pretty well in some sub-indexes, but low levels of entrepreneurship and opportunity, and a bad score in the education sub-index mean that the Legatum Institute ranks it as one of the 20 least prosperous countries on Earth. Overall, it is unmoved from last year's rankings (Will Martin, 2016) ${ }^{10}$. The late Ethiopian prime minister is noted for having presided over double-digit GDP growth, but as The Guardian noted, "poverty and intolerance ... stain his legacy." 11.In his article Ethiopia's Unrest Sparked by Unequal Development Record ${ }^{12}$, Abbink (2016) had succinctly composed this unequal development and the new round of turmoil and severe state repression. In a similar article, Schemm (2017) outlined the strong and pervasive class and regional differentials pertaining to development outcomes. He captured the gravity of the problem in relation to the latest catastrophic landslide at the Ethiopian capital's main garbage dump that left several hundred bodies buried under a wall of trash and dirt, mostly women and children. "This year has not been kind to 
Ethiopia, including widespread popular unrest, drought in many parts of the country, a cholera outbreak and stampede at a culture festival. Yet the deaths at the Addis Ababa landfill on Saturday stands out as a sobering counterpoint to the country's boasts of economic progress." 13.

Twenty years ago, Assefa Negash (1996) wrote a book entitled The Pillage of Ethiopia by Eritreans and their Tigrean surrogates. ${ }^{14}$. That was at high time when the Eritrean regime, Eritrean peoples Liberation Front (EPLF) and the Ethiopian regime/TPLF were hand in hand, which means before the "Ethio- Eritrea war" in 1998. Already 4 years into their reign, "Ethiopia is being sacrificed to fatten Tigrai and Eritrea" (p. xi). The statements made in that book still ring true. They are corroborated with data from latest sources which span 20 years, as you will see later in the body text. "For the first time in Ethiopia's long history, a ruling class has chosen its own ethnic group as its sole constituency. This ruling class now benefits this constituency, in return expecting all the necessary support it needs to stay in power. This is in stark contrast to former Ethiopian rulers whose constituencies were made up of groups of individuals who sought to earn their living by serving the powerful as soldiers and followers. Those rulers recognised no particular ethnic group as their special constituency from which they drew their retainers. Therefore, the defeat of their army usually meant the demise of their regime, because they had no ethnic beneficiary to rescue them with new recruits in sufficient quantity and speed. Their followers, rightly regarded as soldiers of fortune, had no qualms about changing their allegiance overnight. If these soldiers represented any ethnic group it was the Ethiopian nation." (p. xii, Preface by the respected historian Professor Getachew Haile, in Negash, 1996). In Negsh's book the focus was predominantly on the control of material resources and institutions by the regime and the transfer and robbery of resources (see also Steinman, 2017). ${ }^{15}$. In this regard, an article which recently appeared on Forbes entitled "Ethiopia's Cruel Con Game"16. (March 6, 2017) captured vividly the illegal transfer of money and looting. The article stated that two numbers tell the story in a nutshell: "The amount of American financial aid received by Ethiopia's government since it took power: $\$ 30$ billion and the amount stolen by Ethiopia's leaders since it took power: $\$ 30$ billion. The latter figure is based on the UN's own 2015 report on Illicit Financial Outflows by a panel chaired by former South African President Thabo Mbeki and another from Global Financial Integrity, an American think tank. These document \$2-3 billion-an amount roughly equaling Ethiopia's annual foreign aid and investment-being drained from the country every year, mostly through overand under-invoicing of imports and exports. Ethiopia's far-left economy is centrally controlled by a small ruling clique that has grown fantastically wealthy. Only they could be responsible for this enormous crime. In other words, the same Ethiopian leadership that's begging the world for yet another billion for its hungry people is stealing several times that amount every year".

This introduction is to provide a context in which I want to frame my thesis which revolves around a trend in intellectual genocide in Ethiopia and the de-intellectualization of Ethiopian's institution of learning. The focus is on intellectual damages and unequal distribution of intellectual resources and ethnic based inequalities in scholastic achievement.

The philosophical foundation/methodology that undergird this study is critical theory 17 . with elements of poststructuralism and postcolonialism. The theory seeks "to liberate, in this case the oppressed masses of Ethiopia, from the circumstances that enslave them" and that "ideology is the principal obstacle to human liberation."18. In our case the ideology of TPLF that is Stalinism that evolved into the so-called revolutionary democracy. The strategies used to collate and collect data is meta-analysis (data synthesis), some form of discourse analysis, personal accounts, and a limited amount of sociological introspection ${ }^{19}$. Introspection as a sociological process can generate interpretive materials from self and others useful for 
understanding the lived experience of emotions. Analysis is based on interpretation of the news based on evidence, including data, as well as anticipating how events might unfold based on past events.

\section{STRUCTURAL RACISM/ETHNIC APARTHEID IN THE MAKING?}

In this thesis, structural racism/ethnic apartheid in Ethiopia is construed as the normalization and legitimization of an array of dynamics - historical, cultural, institutional, and interpersonal - that routinely advantage the Tigran elite while producing cumulative and chronic adverse outcomes for people of Ethiopia. It is a system of hierarchy and inequity, primarily characterized by Tigran elites Supremacy - the preferential treatment, privilege and power for ethnic Tigran people at the expense of Amhara, Oromo, and other ethnically/racially diverse and oppressed people of Ethiopia.

The situation is urgent and we note that an adequate response to grave injustice of this nature must involve immediate social structural changes to help the communities ravaged by systematic discrimination and conflict. The solution to address this ethnic-based discrimination is genuine democratization and the creation of institutions of civil society. Only then can the underlying causes of injustice perpetrated by the elites be remedied. The gravity of the matter reminds me of Elie Wiesel's most memorable words of wisdom (Elie was an outspoken human rights activist whose words informed and inspired millions around the world, as he advocated for social justice and implored people to remember the Holocaust). He said in his Nobel Peace Prize acceptance speech on Dec. 10, 1986, "We must always take sides. Neutrality helps the oppressor, never the victim. Silence encourages the tormentor, never the tormented. Sometimes we must interfere. When human lives are endangered, when human dignity is in jeopardy, national borders and sensitivities become irrelevant. Wherever men or women are persecuted because of their race, religion, or political views, that place must-at that moment-become the center of the universe." That rings true for Ethiopia as neutrality is destroying the nation's intellectual force in front of our eyes.

My thesis here is that the regime in Ethiopia appears to advance ethnic apartheid, racism and discrimination against other ethnic groups. These include perceived inequitable benefits from more than a decade of "double-digit economic growth,"20. favouritism, nepotism, landgrabbing, and looting national treasures. Mass peaceful protests and brutal government crackdown of dissent is a common scene in Ethiopia. The Ethiopian People's Revolutionary Democratic Front, the coalition that has governed Ethiopia for 25 years and controls every seat in the Addis Ababa parliament, unashamedly states that they are democratic and fair. The recent riot that engulfed Ethiopia clearly shows that people want total change. The masses of Ethiopia demand a free and fair election. Any mention of this fact costs life in the Ethiopian context. Although the situation in Ethiopia appears quiet at a surface level as a result of the state of emergency, the rulers are in a fight for survival as they combat unprecedented levels of discontent which manifested itself in the combined efforts of the two giant ethnic groups (The Amhara and the Oromo) demanding a complete change. In her study, Bezawit Beyene (2011) ${ }^{21 .}$ rightly concludes that the federal system, introduced to avert ethnic conflict and secessionist tendencies, was not able to achieve its goals. The centralization of economic and political power at federal level violates the principle of self-governance and of democracy in general. It is also jeopardized by ethnic favoritism, state partiality, and the absence of a commitment to a national goal. Secessionism still threatens Ethiopia's stability (see also Aalen, 2011). ${ }^{22 .}$

As known, the regime, which is dominated by ethnic Tigreans, who comprise only 6 per cent of the population, hold onto the most powerful positions in the government. They have full 
control in all aspects of life, in the military, in the economic sector, in the social sector, in education and in the political sphere. As education is my area of speciality and research domain, I will focus on that, leaving the economic, military, and political mishaps to the professionals in the field. The only thing I know for sure, and on which everybody agrees with me, is that the distribution of wealth has shifted dramatically in favour of the wealthy and the TPLF elites; and while some economic benefits have trickled down to several ethnic regions in Ethiopia, the main beneficiary, by all accounts, is the Tigrean region creating huge and chronic disparities (personal communication with a United Nations expert, 2017; Education Statistics Annual Abstract $(2014 / 15)^{23}$.

For my purpose, intellectual genocide is defined as three pronged:

1) A systematic discrimination against certain groups with regard to educational opportunities, higher education, and scholarship grants. This involves considering multiple factors such as the technology, teacher support, and learning task or educational affordances that are needed. Inequitable educational affordances of a ubiquitous Learning Environment.

2) Brain draining: The movement of Ethiopian intellectuals like University lecturers and researchers has increased under the TPLF regime. Some observers say that Ethiopia has become a substantial net exporter of academic talent, a so-called brain drain. The condition suggests that the provider nation is at risk of depleting its natural supply of intellectual talent. As far as I understand the movement, it is partly due to lack of employment and low salaries, and thus people are tempted to look for better salaries elsewhere; here, we talk about economic factors. However, the main cause of migration in Ethiopia is political instability, losing confidence in their government and future prospects for a better life. These are individuals who may have difficulties because of their ethnic, cultural, religional belongings or being a member of opposition political groupings: Migration taking place in response to wars, and political and social turmoil. Concerning intellectual migration, Ethiopia (and Africa at large) suffers most from this "unfortunate phenomena." Worth noting also is that in such a country marred by polarization that penetrated all layers of life, it is not only academicians who flee. This category should be called intellectual workforce, because academicians and engineers are joined by artists and musicians. The recent protests in particular in Oromia and Amhara regions and the wave of arrests and purges in its follow-up throws Ethiopia back at least 60 years. As it is being said often these days, academia in Ethiopia has become "desertified." The exodus of qualified people brings economic, cultural and social progress to a standstill: you don't invest your money, you stop publishing books and, if you are under oppression, you can't teach; if you can't criticize there won't be any innovation, no exchange of ideas. The efforts to widen selfcensorship and endless praising of a single ethnic based party under every condition and about every issue doesn't help produce science, art or technology. If Ethiopia has not been granted a radical change towards democratization, it will turn even more conservative, fascist and more consumerist. This is the saddest part.

3) Cultural genocide $24 .:$ Cultural genocide is a strong term and the definition is contentious in the international literature. For my purpose, it refers to the action of the regime with the aim or effect of depriving Ethiopians of their integrity as distinct peoples, or of their cultural values or ethnic identities and trying to construct a new narrative on the origin of Ethiopia; it also includes the action of the regime, which has the aim or effect of dispossessing the people of their lands, territories or resources, as we see, for instance, in Gambela region, in Oromia region, in Wolqait Tegede, and in North Wollo region. The agony of the Wolqait Tegede people is, in particular, a telling example of depriving them of their integrity as distinct people and dispossession of their lands, territories, or 
resources; these people were forced to assimilate into the Tigrean culture and language; and it is technically imposed on them by legislative, administrative, or other measures. ${ }^{25}$. One aspect of this cultural destruction or disintegration of social fabrics and networks is tied to large scale land investments by foreigners. As Abbink (2011: 609) captured, "A new phenomenon since c.2006 is that of the federal and regional governments handing out huge tracts of land for commercial agrarian investment, mostly to foreigners, against lease fees and easy conditions. Most of the land is said to be unproductive and empty terrain, fit for cultivation. Partly this is true. But a large portion of these lands is also used in a low- intensity manner by local groups as essential livelihood supplement (e.g., livestock pasture, forest product gathering, beekeeping, shifting cultivation, water supply). The figures are staggering, and the land being formally state property is easily alienated from local people and then fenced off. In many cases, proper socio-ecological assessment studies have not been carried out, and the idea of serious dialogue about the plans is absent. Again ethnic minorities, although not the only ones affected, are especially vulnerable because they cannot defend their rights (small numbers, lack of language knowledge and regional connections). The options for local people are to move out and migrate to other areas, or to become (low-paid) labourers on the newly established mega-farms, taken out of their social fabric and networks. Alternative areas or facilities are not prepared for them and many are lost and become destitute" (see extensive references there in).

In this thesis, I will focus on three dimensions of this unfortunate phenomenon. First, the disproportionate representation of members of the Tigran ethnic group in higher education and scholarship grants and exploitation of intellectual resources of the nation. Second, I will attempt to outline the causes and facilitating factors of the brain drain. Third, I will try to investigate or reflect on the cultural genocide that affected some groups.

A number of Ethiopian academics informed me that they have witnessed that ethnic Tigreans' are and were disproportionately assigned to the most sought after disciplines and academic positions including scholarships, partly at the expense of members of other ethnic groups, in particular the Amhara ethnic group. By disproportionality, I mean "the underrepresentation or overrepresentation of a racial or ethnic group compared to its percentage in the total population." The unequal outcomes of one racial or ethnic group as compared to outcomes for another racial/ethnic group can be defined as disproportionality or disparity (Farkas, 200326.; Huck, 2008). ${ }^{27 .}$ I still need a good deal of hard facts, statistical figures, and a corpus of interview data to corroborate my account of the injustices and discrimination in that regard. As this is heavily sensitive and inflammatory matter that incites a further lodge between different ethnic groups, I am using scientifically measured restraining phrases and statements. As my friends and colleagues know, I am not a political person and am not writing to favor certain ideology or side with party politics or for that matter any ethnic group.

\section{Genocide}

In his book, Axis Rule in Occupied Europe, Lemkin offered the definition of "a coordinated plan of different actions aiming at the destruction of essential foundations of the life of national groups, with the aim of annihilating the groups themselves" (Lemkin 1944, 79).28. Genocide can be committed in a number of ways, including killing members of a group or causing them serious mental or bodily harm, deliberately inflicting conditions that will bring about a group's physical destruction, imposing measures on a group to prevent births, and forcefully transferring children from one group to another. In this context, genocide does not necessarily 
mean the immediate destruction of a nation. The objectives of such a plan would be the disintegration of the political and social institutions, of culture, language, national feelings, religion, and the economic existence of national groups, and the destruction of the personal security, liberty, health, dignity, and even the lives of the individuals belonging to such groups. In this paper the focus is on the destruction of the basis for intellectual development. ${ }^{29}$. The crime of genocide is defined in international law in the Convention on the Prevention and Punishment of Genocide. ${ }^{30 .}$

I am so outraged and deeply concerned about the continuous injustices and discriminatory practices imposed on the gentle and far sighted Ethiopians which, to make things worse, are perpetrated under the shield of the law and in the name of justice. While I say I am outraged, I know this quiet consuming rage has uplifted me to passionately involve into this terrain: as "Rage - whether in reaction to social injustice, or to our leaders' insanity, or to those who threaten or harm us - is a powerful energy that, with diligent practice, can be transformed into fierce compassion." - Bonnie Myotai Treace. My overall impression and observation of life, if we ever call it life, in Ethiopia after the fall of the repressive Derg regime, is rather than justice for all, we are evolving into a system of justice for those who belong to a privileged ethnic group and who can afford it. We have a network of complex institutions that are not only too big to fail, but too big to be held accountable. However, as we stand up for an ideal, or genuinely act to improve the lot of our long suffering Ethiopians, or strike out against injustice, we definitely sweep down these walls of oppression and resistance.

Tadeos Daniel (2015) in his compellingly insightful article The De-intellectualization of Addis Ababa University and Beyond skillfully outlined how higher institutions in Ethiopia became subservient to the political system and the anti-intellectual nature of the rulers, stifling critical thinking and all-around cultivation of the intellect in favor of a narrow utilitarian approach:

"Education for political consciousness" and "education for class struggle" became the driving forces behind university education heralding loudly the purely utilitarian purpose of education. The liberal arts education philosophy that guided teaching and research at the AddAU for decades was assaulted by this narrow utilitarian approach. The purpose of such an education was just to produce technicians who would subserviently serve the interest of the State. This change in philosophy and practice of education brought about a deleterious effect on the all-around cultivation of the intellect. The dictatorship which replaced the Derg perfected the art of de-intellectualization of the institution and continues with much intensity and fury as I write. In other words, the actions that took place during the time of the Derg are zealously continued by its successor only with more intensity and subtlety.

The early anti-intellectual nature of TPLF was demonstrated in what transpired at the university community meeting the leadership organized early. Spearheaded by such personalities as Bereket Semon, Tefera Walewa, and others, the group exhibited no contrition in tarnishing the history of the Ethiopian polity. Their pretentious and juvenile critique of Ethiopian history was made in the presence of such giant students of Ethiopian history as Professors Tadesse Tamerat, Merid Wolearegay, Bahru Zewde, and Shiferaw Bekele. No humility and deference were shown.

These individuals were either high school or college dropouts at the time they were aggressively pushing their tall tales. Con artists of the highest order, they were pretending as if they had a specialized graduate training in Ethiopian history when in fact they had none whatsoever. The swindlers were simply showing their distaste and disrespect to the academy. 
Power became synonymous with knowledge all at once. Power usurped through the barrel of the gun turned to become the source of knowledge. Egotism and conceit replaced modesty and humility. The pseudointellectual began to reign over the intellectual. The mirage of knowledge inched into replacing real knowledge. ${ }^{31 .}$

\section{Some Statistics: Ethnic Inequalities, Regional Differences and Institutional Intransigencies}

The expulsion of the 42 academics from the Addis Ababa University (AAU) is motivated by the anti-intellectual traits of the rulers. Their only crime might be that they speak their minds as a decent scholar does; they might have engaged in pursuit of truth or open discussions or critical discourses that are germane to the nation. Or most of them, as some observers wrote, might have belonged to the wrong ethnic group. The expulsion was a message that scholars have no role in appraising the political and economic development of the regime. As Daniel (2015) succinctly stated, "It [the summary dismissal] was intended to send a clear warning to all who may dare to engage in the critical appraisal of the TPLF; a message to declare war on freedom of expression and underscore the virtue of ideological conformity at the University. This was a travesty and an oxymoron. Intellectual work and scholarship never intersect with docility and conformity. This indeed is contrary to the pillars of higher education." Those dismissed at AAU in 1993 included five of the University's eleven full professors, its only specialists in some fields, and professors who had won international recognition for their scholarship. Some of them were subsequently harassed by government soldiers. The government also made efforts to ensure their continued marginalization, for example by intimidating their families and friends and staff of NGOs that hired them. Yet another professor, Fesseha Zewde of the history department, was dismissed in June of the same year ${ }^{32}$. (see also Negash, 1996).

Apart from discharging senior researchers and scholars in specialized fields who were labelled as belonging to the "enemy ethnic group," Tigreans tend to grab those academic positions including leadership posts. "...out of 60 medical doctors who recently applied for specialization at the Department of Gynecology/obstetrics, 15 candidates were admitted. Of the 15, 11 were Tigreans. The Department of Pediatrics of the Addis Ababa Medical School was equally ethnically cleansed recently and a Tigrean named as its head" (Negash, 1996). The same pattern has been applied unabatedly throughout the TPLF reign ${ }^{33 .}$ (see also Interview with Paul 0'Keefe ${ }^{34}$. for latest miscarriage of justice). The Scandinavian languages have a word, the Swedish variant of which is justitiemord, which literally translates as justice murder. (see also The Cruel Political Jokes of the T-TPLF in Ethiopia Alemayehu G. Mariam (June 26, 2017) ${ }^{35 .}$

I myself experienced first-hand that all but one department positions in my former place of work were replaced by Tigreans. That happened in front of my eyes within a span of 2 months after the TPLF came into power. I was Acting Head of the External Relations Division/Department of the Rehabilitation Agency for the disabled. I was expecting to be the head of the Department. That position was given to an Oromo speaking person who was TPLF's poodle/lapdog or lackey. The other department head positions were filled by incompetent and lazy colleagues of Tigrean origin. This was the standard of the day when I was still servant of the Agency; and the practice happened elsewhere in Ethiopia. The recognition of this grim reality sends chills up one's spine; I then decided to leave my beloved country for good. According to all accounts, that practice has gotten worse during my absence.

Moreover, the Amhara ethnic group have faced discrimination from the TPLF and other ethnic groups who saw them as the allied oppressor of previous governments. Amhara were expelled from important positions in the 
bureaucracy and from various regions, especially Oromiya (Young 1996:536; Teshome 2009:63). These actions were seen as the dawn of another ethnic domination in Ethiopia and as sowing the seeds of further ethnic tension. The 2005 election revealed latent ethnic tensions when the government and political parties each described the other as a threat to the well-being and security of another particular ethnic group (Beyene, 2011. p. 49) ${ }^{36 .}$

The poor achievement of the Amhara youth in the Amhara region in matriculation examination has yet to be explained! (I will get back to this in the second part of the article). In a radio interview conducted this past summer with teachers, political officers and school officials of the Amhara region about the reason behind this poor achievement, all the respondents put the blame squarely on the motivation level of the students and their incessant obsession with social media. The parents were also blamed for not disciplining their children. There was no mention of structural or systemic defects. This is a good example of scapegoating and blaming-the-victim discourse. Scapegoating and creating a "denigrated" other has become a fundamental component of public policy today. It has become a useful and perhaps necessary tactic that allows the wealthiest of the population to focus public debate on the "other; " the unworthy poor, terrorists, or immigrants who threaten our borders. This strategy may partially explain how it has been possible to redistribute or loot such large amounts of wealth to an affluent few or TPLF elites without serious protest from the vast majority of people who not only have not benefited, but who have actually lost ground, including in their national pride and in their country. Scapegoating, which relies on the ability to dehumanize and demonize relatively powerless populations or ethnic groups defined as "other," has effectively served to distract most citizens from recognizing the economic and social inequities that have increasingly permeated the Ethiopian society over the past 25 years $^{37}$. (see Miller \& Schamess, 2000).

Based on statistical analysis, Ajala and Asres (2008) ${ }^{38}$. revealed that there is a gross inadequacy in the provision of facilities and personnel to adequately prepare the youth for their future, in Amhara region. The study also revealed the inequality of accessibility to basic education services among the 11 administrative zones in the region, with antecedent impact on the development levels among the zones and the region at large. The authors argued further that the current number of higher education preparatory schools in Amhara region run contrary to the present government policy on higher education. The federal government has recently established more universities in the country to increase access to university education in Ethiopia. However, in Amhara region there are 24 higher education preparatory schools, which is a prerequisite to regular university admission. This is quite inadequate for the number of students completing their grade 10, thus it puts the students from Amhara region at a disadvantage among the nine regions in Ethiopia. It shows a high level of inaccessibility to education. One important observation about the distribution of the schools in Amhara region is that there is a wide gap between the numbers of schools available for different levels of education. There are 4177 schools of all types for both primary and secondary education in the region, grade 1-8 schools account for $97 \%$ (4056 schools), grade $9-10$ is just 2\% (97schools) and grade 11-12 account for 1\% (24 schools). This gap portends that a large proportion of students lack access to further their education beyond grade 8 on a regular basis.

Addis Ababa Science and Technology University (AASTU) was founded in 2011, and is a public higher education institution located in the large city of Addis Ababa. Officially accredited/recognized by the Ministry of Education, AASTU is a coeducational higher education institution. It offers courses and programs leading to officially recognized higher education degrees such as bachelor degrees in several areas of study. According to a staff 
member who was interviewed for this purpose over the phone: “. . the overrepresentation of Tigreans both as staff members as well as students is visible. It is a matter of fact. It is not a matter of opinion. I have no clues how either the student groups or the staff end up here with us. In any case Tigreans presence is highly felt both in academia and decision making organs. Too many things are subtle and unpredictable. No transparence! No openness."

The informant is aware that this is about the phenomenon of disproportionality that is the unequal outcome or presence/admissions of one racial or ethnic group as compared to outcomes or presence/admissions for another racial/ethnic group.

Although the government has made efforts to expand higher institutions of learning in different regions, the quality of education is highly questionable. The Guardian (2015/2017) in its article Ethiopia's Higher-Education Boom Built on Shoddy Foundations ${ }^{39}$. has rightly pointed out that the country desperately needs new universities to drive development, but most of the 30 built in the last 15 years fall woefully short. Ethiopia's higher education infrastructure has mushroomed in the last 15 years. But the institutions suffer from curricula being abandoned due to funding cuts, unqualified (but party-loyal) lecturers, and shoddily built institutions. The rapid growth of Ethiopia's higher education system has come at a cost, but it is moving forward all the same. The quality of these new universities varies widely; from thriving research schools, to substandard institutions built to bolster the regime's power in hostile regions. One professor recalls a hurried evacuation from part of a recently completed university while he was working there: one of the buildings had collapsed. Undoubtedly the thriving research schools and university colleges are located in the Tigrean region, such as the Mekelle University with its affiliated technological institutions (Ibid).

The number of Universities has increased to 30 plus. Among these, Asossa University is one of them. The University was established in 2011. It is located $675 \mathrm{~km}$ northwest of Addis Ababa at Asossa town, which is the capital city of Benishngul Gumuz Regional State. According to a Swedish researcher who visited the University last year, ". . . what is most depressing and worrisome is the lack of qualifications among the staff. Most of the staff members have just graduated with BAs and MAs. In many ways it is embarrassing and saddening to witness the extremely poor quality of education afforded in this peripheral colleges."

The professor, who was interviewed by the Guardian, reiterated that "A lot of the time the universities are merely shells. They do not function as universities as we would expect and are poorly resourced, and in some cases shoddily built. It would seem that they are built almost as a token where the EPRDF can say to hostile regions 'look we are doing something for you, we've built a University.'” The professor commented further "Reports of spies, classroom propaganda, of curricula that have been abandoned en mass due to funding cuts, and of unqualified staff are common at these universities, which make up the bulk of Ethiopian higher education. The party line is peddled during class, students are required to join the party, [there are] various reports of spies in the classrooms, who monitor what is said and who says it." (see Interview with Paul O'Keefe.) ${ }^{40 .}$

The researcher (my informant) who recently visited the Asossa University pointed out the benefit of speaking Tigrean language. The informant meant that the staff members told him that they elect Tigreans or Tigran speaking members because being tigraen and/or speaking Tigrigna help facilitate things in the complex bureaucracy labyrinth in the Ethiopian federal system: "People seem to fear Tigreans. They have the power. It is easier for Tigreans to navigate in the system and make things happen. So there is a tendency to nominate and elect 
Tigreans for different positions for the mere reason of facilitating errands. People are terrified by the presence of Tigreans. A sad scenario" according to Mebratu one of my informants.

The benefits of Tigrean language or being Tigrean in contemporary Ethiopia is an area to be closely looked at using an anthropological/ethnological approach. It is a complex hegemonic process which continues to sustain the pre-eminence of Tigreans and Tigrean language in Ethiopia. The view of language as a type of wealth-accumulation has already been revealed in the social capital literature. Being a type of capital, social capital is a subspecies of (accumulated) power. This shows Tigrigna as a linguistic/social capital. Linguistic capital is one of the forms of cultural capital. It is inherited or acquired over time, not transferable, and it influences one's habitus. Affected by the surrounding environment, it is likely for one to recognize the power of a linguistic product/feature and become one of the producers of such product. One possesses power if his/her language is being seen as legitimate, as we have seen in the above interview excerpt (see Swartz, 1997, for a better theoretical understanding of the phenomenon $^{41}$ ). Bourdieu (199142.) argues that parents pass down their economic, cultural, and social resources to their children so that their children benefit from the advantages and perform successfully at school and in the labor market in the future. That is what happens now in Ethiopia among the rich and ethnic Tigreans. These children will turn out to be more successful and advantaged in terms of the quality of the education they receive and their occupations over the other children. A good example is the proliferation of exclusive boarding schools in the Tigrean region for the ethnic Tigrean youth. Qalamino stands out as remarkably top level. It's a privilege that the elite of the Ethiopian society presume to be a right, and members of other ethnic groups may never experience due to the downright exclusivity of admission. The main criteria being ethnicity! Children from middle-class and upper-class families will benefit more from their parents' transmission of resources (in most cases unfairly accumulated) to them since their parents possess more resources, especially political, economic, and military, they will have a larger and better social network than the parents in the future. That is what we are witnessing in Ethiopia. That is the strong and pervasive evidence of ethnic/class inequalities in Ethiopia (see also Portes, 199843.).

The following data show the disparities along regional, ethnic, gender, class, and urban/rural measures. According to the 2011 Ethiopia Demographic and Health Survey (2011 EDHS), which is part of the worldwide MEASURE DHS project funded by the United States of America's Agency for International Development (USAID), educational attainment in Ethiopia is much higher among the urban population than among the rural population. For example, in urban areas $28 \%$ of females and $15 \%$ of males have no education, compared with $58 \%$ of females and $44 \%$ of males in rural areas. Among regions, the proportion of females and males with no education is highest in Affar (69\% and 53\%, respectively), followed by Somali for women $(68 \%)$ and Amhara for men (47\%), and lowest in the capital city, Addis Ababa (23\% and 10\%). The highest percentages of females and males who have completed secondary or more than secondary education live in the urbanized regions, such as Harari, Addis Ababa, and Dire Dawa. The most substantial variation in educational attainment occurs across the wealth quintiles. Only $27 \%$ of females in the wealthiest households have no education, compared with $69 \%$ in the poorest households. Among males, 14\% of those in the wealthiest households have no education, compared with $54 \%$ in the poorest households. ${ }^{44}$.

A very recent article, Ethiopia Crises Force Millions Out of School ${ }^{45}$. reveals that millions of children are out of school in Ethiopia as the East African country endures successive natural disasters and conflict. According to the Education Management Information System (EMIS) of the Ministry of Education, the number of children and teachers affected by the crises increased from 2, 1 million in December 2015 to 4 million in June 2016. The report further reveals that 
Assessment data show that about $76 \%$ of primary schools in nine regions have no water available on school premises and $47 \%$ of schools are without latrines. "As a result, children's school attendance is erratic and in some cases children drop out of school entirely due to families migrating in search of water" said a UNICEF spokesperson. It is estimated that about 2 million school-age children in hotspots require school feeding in 2016/17 academic year. In many affected areas teachers reported a lack of student attentiveness in the classroom and low attendance rates due to limited provision of school feeding. This is happening in Ethiopia while the regime is boasting about its double digit economic growth. Still worse, the affected regions are the ones which have been neglected because of political reasons (Posted by ethioforum on June 23, 2017). The Tigrean region is least affected by this.

The following tables and charts show some of the regional disparities in educational affordance/opportunities, material, and services among the different ethnic based regions (Education Statistics Annual Abstract (2014/15).

\section{Gross Enrollment Rate (GER) for Early Childhood Care and Education}

Gross Enrollment Rate (GER) is a ratio obtained by dividing the total enrollment of preprimary students by the expected official preprimary school age population. Table 1 below shows the data regarding enrollment of students in each region associated with the official expected population size and calculated result.

Table 1. School Age Population (age 4-6), Enrollment, and by Region 2014/15.

\begin{tabular}{|c|c|c|c|c|c|c|c|c|c|}
\hline \multirow[t]{2}{*}{ Regions } & \multicolumn{3}{|c|}{ School Age population(4-6) } & \multicolumn{3}{|c|}{$\begin{array}{l}\text { Enrollment in preprimary(all } \\
\text { age) }\end{array}$} & \multicolumn{3}{|c|}{ GER (\%) } \\
\hline & Male & Female & Total & Male & Female & Total & Male & Female & Total \\
\hline Tigray & 194,132 & 188,703 & 382,835 & 191,221 & 187,383 & 378,604 & $99 \%$ & $99 \%$ & $99 \%$ \\
\hline Afar & 67,649 & 64,008 & 131,657 & 5,932 & 5,038 & 10,970 & $9 \%$ & $8 \%$ & $8 \%$ \\
\hline Amhara & 856,070 & 828,267 & $1,684,337$ & 355,972 & 335,356 & 691,328 & $42 \%$ & $40 \%$ & $41 \%$ \\
\hline Oromiya & $1,496,937$ & $1,469,129$ & $2,966,066$ & 380,433 & 343,531 & 723,964 & $25 \%$ & $23 \%$ & $24 \%$ \\
\hline Somali & 248,116 & 242,829 & 490,945 & 33,647 & 27,273 & 60,920 & $14 \%$ & $11 \%$ & $12 \%$ \\
\hline SNNP & 772,580 & 758,110 & $1,530,690$ & 456,788 & 417,142 & 873,930 & $59 \%$ & $55 \%$ & $57 \%$ \\
\hline $\begin{array}{l}\text { Benishangul- } \\
\text { Gumuz }\end{array}$ & 42,527 & 41,128 & 83,655 & 16,920 & 14,983 & 31,903 & $40 \%$ & $36 \%$ & $38 \%$ \\
\hline Gambella & 15,039 & 14,662 & 29,701 & 3,879 & 3,631 & 7,510 & $26 \%$ & $25 \%$ & $25 \%$ \\
\hline Harari & 8,063 & 7,699 & 15,762 & 6,961 & 6,184 & 13,145 & $86 \%$ & $80 \%$ & $83 \%$ \\
\hline Addis Ababa & 84,963 & 84,766 & 169,729 & 77,750 & 75,081 & 152,831 & $92 \%$ & $89 \%$ & $90 \%$ \\
\hline Dire Dawa & 19,447 & 18,119 & 37,566 & 7,291 & 6,407 & 13,698 & $37 \%$ & $35 \%$ & $36 \%$ \\
\hline National & $3,805,523$ & $3,717,419$ & $7,522,942$ & $1,536,794$ & $1,422,009$ & $2,958,803$ & $40 \%$ & $38 \%$ & $39 \%$ \\
\hline
\end{tabular}

Source: Education Statistics Annual Abstract, 2014/15. 


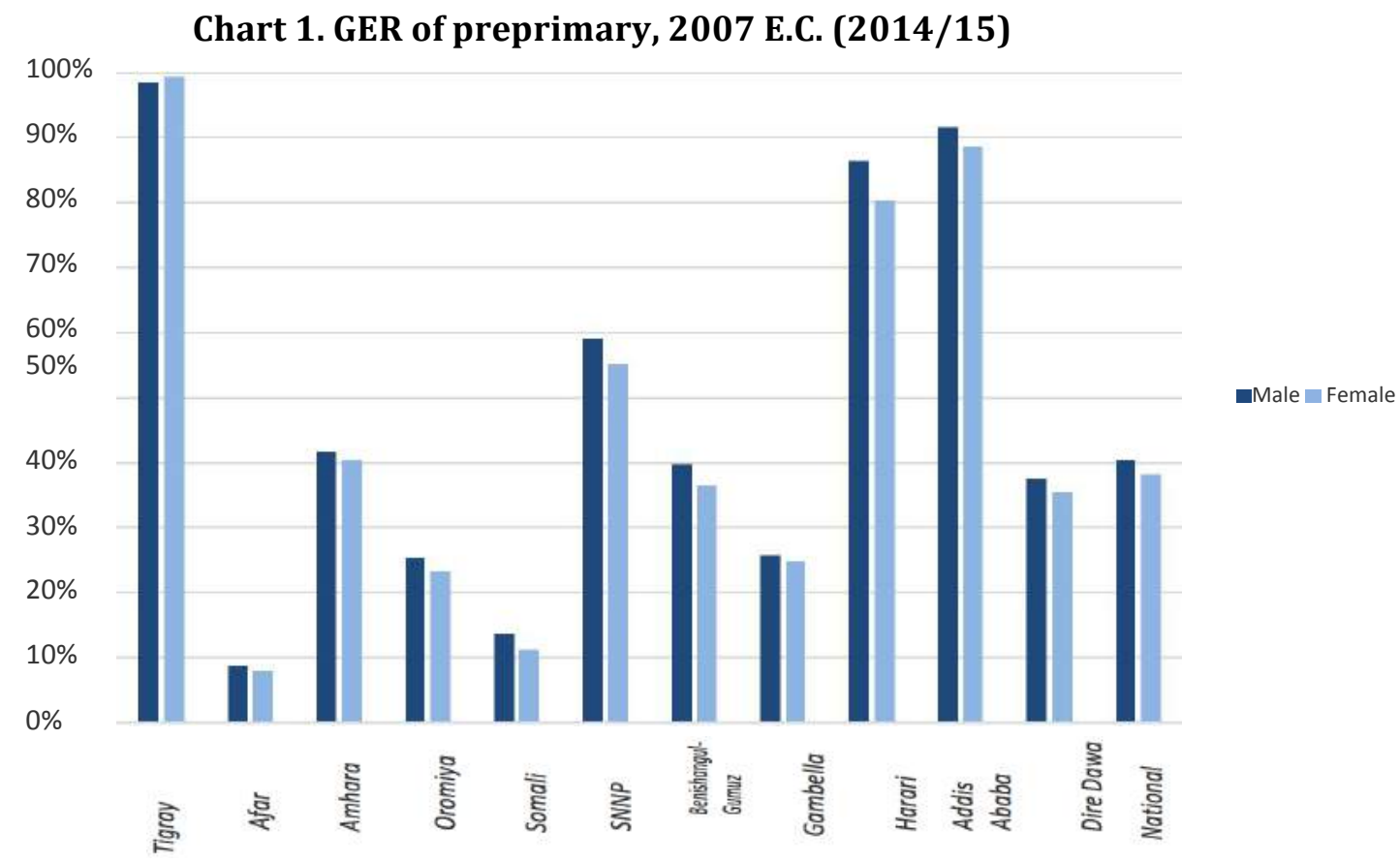

As shown in both Table 1 and its associated Chart 1, the national gross enrollment rate is 39\% and the gross enrollment rate for girls has attained 38\%. However, if we look at regional achievement, Tigray, Addis Ababa, and Harari attained the highest GER: 99\%, 90\%, and 83\%, respectively. By contrast, the achievement by Gambella, Afar, and Somali $(25 \%, 8 \%$, and 12\%, respectively) attained the lowest GER.

\section{Adjusted Net Enrollment Rate}

The calculation that has been used traditionally to calculate NER, and is shown above, includes only those children who are between 4 and 6 and enrolled in preprimary programs. This excludes those children who have enrolled in primary school grades who are under 7. For example, there may be 6-year-olds who have enrolled in grade 1 in a primary grade who would be excluded from both the preprimary NER and the primary NER because they have not enrolled in the correct modality for their age, according to Education Statistics Annual Abstract (2014/15, see Table 2). 
Table 2. Preprimary Adjusted NER, 2014/15.

\begin{tabular}{|c|c|c|c|c|c|c|c|c|c|}
\hline \multirow[t]{2}{*}{ Regions } & \multicolumn{3}{|c|}{ School Age population (4-6) } & \multicolumn{3}{|c|}{$\begin{array}{l}\text { Enrolment of preprimary ( } 4-6) \\
\text { and } \\
\text { under } 7 \text { year olds in primary } \\
\text { grades }\end{array}$} & \multicolumn{3}{|c|}{ NER (\%) } \\
\hline & Male & Female & Total & Male & Female & Total & Male & Female & Total \\
\hline Tigray & 194,132 & 188,703 & 382,835 & 188,235 & 184,632 & 372,847 & $97 \%$ & $98 \%$ & $97 \%$ \\
\hline Afar & 67,649 & 64,008 & 131,657 & 12,855 & 10,813 & 21,260 & $19 \%$ & $17 \%$ & $16 \%$ \\
\hline Amhara & 856,070 & 828,267 & $1,684,337$ & 345,700 & 326,229 & 671,929 & $40 \%$ & $39 \%$ & $40 \%$ \\
\hline Oromiya & $1,496,937$ & $1,469,129$ & $2,966,066$ & 373,459 & 338,026 & 702,478 & $25 \%$ & $23 \%$ & $24 \%$ \\
\hline Somali & 248,116 & 242,829 & 490,945 & 53,062 & 40,472 & 74,197 & $21 \%$ & $17 \%$ & $15 \%$ \\
\hline SNNP & 772,580 & 758,110 & $1,530,690$ & 448,690 & 408,943 & 845,575 & $58 \%$ & $54 \%$ & $55 \%$ \\
\hline $\begin{array}{l}\text { Benishang } \\
\text { ul } \\
\text { Gumuz }\end{array}$ & 42,527 & 41,128 & 83,655 & 16,573 & 14,572 & 30,941 & $39 \%$ & $35 \%$ & $37 \%$ \\
\hline Gambella & 15,039 & 14,662 & 29,701 & 5,611 & 5,029 & 9,244 & $37 \%$ & $34 \%$ & $31 \%$ \\
\hline Harari & 8,063 & 7,699 & 15,762 & 6,302 & 5,619 & 11,921 & $78 \%$ & $73 \%$ & $76 \%$ \\
\hline $\begin{array}{l}\text { Addis } \\
\text { Ababa }\end{array}$ & 84,963 & 84,766 & 169,729 & 78,197 & 77,489 & 155,508 & $92 \%$ & $91 \%$ & $92 \%$ \\
\hline Dire Dawa & 19,447 & 18,119 & 37,566 & 7,053 & 6,229 & 13,282 & $36 \%$ & $34 \%$ & $35 \%$ \\
\hline National & $3,805,523$ & $3,717,419$ & $7,522,942$ & $1,535,737$ & $1,418,053$ & $2,909,182$ & $40 \%$ & $38 \%$ & $39 \%$ \\
\hline
\end{tabular}

Source: Education Statistics Annual Abstract (2014/15: p. 33).

\section{Secondary Gross Enrollment Rate (GER)}

The national GER for $20014 / 15$ is $25.6 \%$ for grades $9-12$ (see table 3). This indicates that nationally there is low enrolment in secondary schools and there are many 15- to 18-year-olds who are not in secondary education. The national figure hides the regional variation that exists, with Addis Ababa, Gambella, and Tigray having a much higher GER compared to the national average. This shows that in these regions secondary education is more wide spread' (see also EDHS, 201146.)

Table 3. Gross Enrollment Rate for Grades 9-12, 2014/15.

\begin{tabular}{|l|l|l|l|l|l|l|l|l|l|}
\hline \multirow{2}{*}{ Region } & \multicolumn{3}{|l}{ Population of Age 15-18 } & \multicolumn{2}{l}{ Enrollment G9-12 (All age) } & \multicolumn{3}{|c|}{ GER \% } \\
\cline { 2 - 10 } & Male & Female & Total & Male & Female & Total & Male & Female & Total \\
\hline Tigray & 232,934 & 228,890 & 461,824 & 94,053 & 98,159 & 192,212 & 40.38 & 42.88 & 41.62 \\
\hline Afar & 88,223 & 66,910 & 155,133 & 14,556 & 7,879 & 22,435 & 16.50 & 11.78 & 14.46 \\
\hline Amhara & 915,582 & 892,137 & $1,807,718$ & 246,007 & 253,031 & 499,038 & 26.87 & 28.36 & 27.61 \\
\hline Oromiya & $1,601,811$ & $1,577,446$ & $3,179,257$ & 368,146 & 307,863 & 676,009 & 22.98 & 19.52 & 21.26 \\
\hline Somali & 266,572 & 231,656 & 498,228 & 37,859 & 18,301 & 56,160 & 14.20 & 7.90 & 11.27 \\
\hline SNNP & 872,105 & 865,624 & $1,737,729$ & 245,154 & 203,530 & 448,684 & 28.11 & 23.51 & 25.82 \\
\hline $\begin{array}{l}\text { Benishangul- } \\
\text { Gumuz }\end{array}$ & & & & & & & & & \\
\hline Gambella & 19,590 & 45,814 & 92,404 & 14,384 & 11,427 & 25,811 & 30.87 & 24.94 & 27.93 \\
\hline Harari & 9,744 & 17,274 & 36,295 & 13,216 & 8,115 & 21,331 & 69.48 & 46.98 & 58.77 \\
\hline Addis Ababa & 86,669 & 9,851 & 19,595 & 3,728 & 3,212 & 6,940 & 38.26 & 32.61 & 35.42 \\
\hline Dire Dawa & 26,860 & 25,120 & 51,980 & 6,419 & 5,363 & 11,782 & 23.90 & 21.35 & 22.67 \\
\hline National & $4,166,112$ & $4,064,313$ & $8,230,425$ & $1,109,877$ & 998,238 & $2,108,115$ & 26.64 & 24.56 & 25.61 \\
\hline
\end{tabular}

Source: Education Statistics Annual Abstract (2014/15). 


\section{Net Enrollment Ratio (NER)}

The NER is similar to the GER and calculates an enrollment ratio (see Table 4). It is different than the GER in that it only takes those of the correct school age for those grades (i.e. it only looks at the 7- to 14-year-olds who are enrolled in primary education. This indicator includes enrollment in Alternative Basic Education (ABE) centres as well as formal primary schools (Education Statistics Annual Abstract (2014/15: p. 44). (See also EDHS, 2011).

Table 4. Net Enrollment Rate of Primary Disaggregated by Region and Gender, 2014/15.

\begin{tabular}{|c|c|c|c|c|c|c|c|c|c|}
\hline \multirow[b]{2}{*}{ Region } & \multicolumn{3}{|c|}{ Age 7-to-14 Population } & \multicolumn{3}{|c|}{ 1-to-8 Net Enrollment } & \multicolumn{3}{|c|}{ NER \% } \\
\hline & Male & Femal & Tota & Male & Femal & Tota & Male & Femal & Tota \\
\hline Tigray & 504,887 & 492,089 & 996,976 & 530,653 & 518,974 & $1,049,627$ & 105.1 & 105.5 & 105.3 \\
\hline Afar & 155,721 & 132,567 & 288,288 & 97,438 & 73,250 & 170,688 & 62.6 & 55.3 & 59.2 \\
\hline Amhara & $1,955,944$ & $1,927,583$ & $3,883,527$ & $1,971,472$ & $1,929,240$ & $3,900,712$ & 100.8 & 100.1 & 100.4 \\
\hline Oromia & $3,719,401$ & $3,665,213$ & $7,384,614$ & $3,454,708$ & $3,058,515$ & $6,513,223$ & 92.9 & 83.4 & 88.2 \\
\hline Somali & 476,031 & 406,094 & 882,125 & 410,464 & 305,237 & 715,700 & 86.2 & 75.2 & 81.1 \\
\hline SNNPR & $2,004,746$ & $1,985,632$ & $3,990,378$ & $2,128,202$ & $1,911,693$ & $4,039,895$ & 106.2 & 96.3 & 101.2 \\
\hline $\begin{array}{l}\text { Benishang } \\
\text { ul }\end{array}$ & 104,936 & 101,067 & 206,002 & 99,068 & 84,933 & 184,001 & 94.4 & 84.0 & 89.3 \\
\hline Gambella & 39,378 & 35,699 & 75,077 & 48,855 & 39,980 & 88,835 & 124.1 & 112.0 & 118.3 \\
\hline Harari & 20,698 & 19,920 & 40,618 & 20,289 & 17,118 & 37,407 & 98.0 & 85.9 & 92.1 \\
\hline $\begin{array}{l}\text { Addis } \\
\text { Ababa }\end{array}$ & 168,939 & 173,586 & 342,525 & 182,186 & 207,529 & 389,715 & 107.8 & 119.6 & 113.8 \\
\hline Dire Dawa & 52,579 & 48,591 & 101,170 & 30,194 & 27,388 & 57,582 & 57.4 & 56.4 & 56.9 \\
\hline National & $9,203,260$ & $8,988,039$ & $18,191,299$ & $8,973,529$ & $8,173,857$ & $17,147,385$ & 97.5 & 90.9 & 94.3 \\
\hline
\end{tabular}

Source: Education Statistics Annual Abstract (2014/15: p. 44).

As seen in Table 4, NER nationally reached 94.3\%, which indicates a high degree of participation of the official school-age population in primary schools. Again there is a high amount of regional variation, with Dire Dawa having a low NER and Gambella, Tigray, and Addis Ababa having an NER greater than 100, which is technically impossible. This indicates the same problems as mentioned when discussing NIR of population inaccuracies and difficulties in recording children that cross regional borders (Education Statistics Annual Abstract (2014/15).

\section{EXAMINATION RESULTS}

According to the Ethiopian education and training policy, a regional examination will be given at grade 8 to certify completion of primary education. The first national examination, the Ethiopian General Secondary Education Certificate Examination (EGSECE), is given at grade 10 to certify the completion of general secondary education and to select students that qualify for preparatory education. Similarly, a second national examination, the Ethiopian Higher Education Entrance Certificate Examination (EHEECE) will be given at grade 12 to place students in higher education institutions (see Table 5). 
Table 5. Grade 8 Examination Results, 2014/15.

\begin{tabular}{|c|c|c|c|c|c|c|c|c|c|}
\hline \multirow[b]{2}{*}{ Region } & \multicolumn{3}{|c|}{ Sat for Exam } & \multicolumn{3}{|c|}{ Number of Promoters } & \multicolumn{3}{|c|}{$\%$ of promoters } \\
\hline & Male & Female & Tota & Male & Femal & Tota & Male & $\begin{array}{l}\text { Femal } \\
\text { e }\end{array}$ & Tota \\
\hline Tigray & 50,186 & 53,328 & 103,514 & 45,677 & 48,207 & 93,884 & 91.02 & 90.40 & 91 \\
\hline Afar & 3,960 & 2,310 & 6,271 & 2,421 & 1,102 & 3,523 & 61.14 & 47.70 & 56 \\
\hline Amhara & 130,393 & 142,599 & 272,992 & 110,189 & 124,115 & 234,304 & 84.51 & 87.04 & 86 \\
\hline Oromiya & 187,834 & 163,475 & 351,309 & 178,517 & 156,391 & 334,908 & 95.04 & 95.67 & 95 \\
\hline Somali & 16,794 & 7,841 & 24,635 & 14,234 & 6,207 & 20,441 & 84.76 & 79.16 & 83 \\
\hline SNNP & 154,775 & 132,588 & 287,363 & 135,334 & 110,605 & 245,939 & 87.44 & 83.42 & 86 \\
\hline Benishangul-Gumuz & 8,890 & 5,914 & 14,804 & 6,978 & 5,005 & 11,983 & 78.49 & 84.63 & 81 \\
\hline Gambella & 6,705 & 4,852 & 11,557 & 5,682 & 4,161 & 9,843 & 84.74 & 85.76 & 85 \\
\hline Harari & 1,401 & 1,173 & 2,574 & 1,260 & 1,151 & 2,411 & 89.94 & 98.12 & 94 \\
\hline Addis Ababa & 28,391 & 37,777 & 66,168 & 21,884 & 26,332 & 48,216 & 77.08 & 69.70 & 73 \\
\hline Dire Dawa & 3,212 & 2,751 & 5,963 & 2,341 & 2,164 & 4,505 & 72.88 & 78.66 & 76 \\
\hline National & 592,541 & 554,609 & $1,147,150$ & 524,517 & 485,440 & $\begin{array}{l}1,009,95 \\
7\end{array}$ & 88.52 & 87.53 & 88 \\
\hline
\end{tabular}

Source: Education Statistics Annual Abstract (2014/15: p. 87).

Note. Data for Afar and Amhara have been estimated as these regions were unable to supply data within the given time frame.

From Table 5 it can be seen that nationally 12\% of those who take the Grade 8 exam do not achieve a grade that allows them to pass the grade and progress to secondary school. There is large regional variation, with Afar and Addis Ababa having the lower pass rates in comparison to other regions (p. 87).

The general impression or preliminary conclusion that one can safely draw from the corpus of statistical data compiled in the Education Statistics Annual Abstract data and Ethiopia Demographic and Health Survey 2011 is that The Tigrean region perform far above the national average in most of the educational measures/indicators. A very recent study on regional/ethnic and gender disparities in academic achievement in Ethiopia has been presented at a conference in Oslo - "Closing the Gaps? Differential Accountability and Effectiveness as a Road to School Improvement" on behalf of the Centre for Educational Measurement at the University of Oslo (CEMO) - by Tesema et al. (2016) ${ }^{47}$. which is in line with my argument above. Unfortunately, the paper is in the process of being published and I could not adapt or use some of the striking figures and charts before it is published.

\section{Scholarship Grants and Research Fellowships}

A scholar who resides in the Netherlands and wanted to be anonymous informed me that "out of 52 scholarship grants that the government of The Netherlands gave to Ethiopia at a specific year, about 50 went to the Tigrean region"! Actually it was this specific information that motivated me to write this lengthy research paper. I presume my respondent is referring to the same information posted on 28 November 2008 by The Ethio Media Forum:

Out of 55 scholarship students who are sent to the Wageningen University (Netherlands) by the ... regime, 50 are ethnic Tigreans .... 'Most of the students came directly from Mekele University in collaboration with Ethiopian Institute of Agricultural Research (EIAR).' Source said. 'But the criterion to follow the Msc. courses appears to be neither excellence nor student's GPA. Rather, ethnic background is the major factor for selection. ${ }^{48 .}$ 
This information has been corroborated with other personal accounts [see interview data on the following page] and one can safely draw a conclusion that it is possible to discern substantial disproportionality in scholarship distributions among ethnic groups. I heard similar stories in several other European countries that scholarship grants abroad are unfairly distributed to different regions. I am still working on this kind of data. A number of universities abroad have been approached to provide data on potential candidates' ethnic origin. The process has been challenging because of difficulties to trace the ethnic origins of the recipients; and it has not been easy to solicit data from the university registrars as I suspect they find the inquiry unusual. Although the response in this regard from various universities abroad (both free and fee charging ones) is not encouraging, I am still investigating other venues to get accurate data. Until the full picture comes out, I will present some sporadic information based on personal accounts.

I interviewed two former students of Wageningen University and the University of Twente, the Faculty of Geo-Information Science and Earth Observation (ITC) to validate the above statements. The master Management, Economics and Consumer Studies in Wageningen, the Netherlands, deals with the interrelationships between producers, consumers and society at large. The programme studies the dynamics in the agri-food chain involving suppliers, producers, retailers, and consumers. It covers managerial, economic, sociological and environmental aspects of households and businesses in the Netherlands, Europe and the rest of the world, in both developed and developing countries. The Faculty of Geo-Information Science and Earth Observation (ITC) of the University of Twente, the Netherlands, provides international postgraduate education, research, and project services in the field of geoinformation science and earth observation using remote sensing and GIS. The aim of ITC's activities is the international exchange of knowledge, focusing on capacity building and institutional development in developing countries and emerging economies. The two respondents are familiar with and active in the two schools in different capacities, in particular during the academic years 2009-2011:

There are various programmes in the Wagenningen University. The master Management, Economics and Consumer Studies is popular among Ethiopian students ... .. you would see large number of students with Tigrean origin. In fact students with other ethnic backgrounds are thinly distributed throughout the university. It is not an exaggeration if I say over $95 \%$ of the student population is just from one ethnic group (Abraham).

The Faculty of Geo-Information Science and Earth Observation (ITC) of the University of Twente is a popular destination for a single ethnic group. I am not sure if they [the school] has a special agreement with a college in the Tigrean region. You see some Ethiopians of other origins here and there in many of the colleges in the Netherlands. But the predominant group comes from Northern Ethiopia. My impression is that differentials in studying abroad and scholarship opportunities are a fact. (Mihret)

A former university teacher currently residing in the United States of America and who claims to have insider knowledge expressed:

It appears that the regime has been benefiting its own ethnic group and political allies. Even in Ethiopia, college admissions quota to high demand fields such as engineering, medicine, and law are reserved for the Northerners [he is referring to the Tigreans] while those with less demand or out-of-market fields are for the rest. In principle, all highly selective college's entering class should be admitted solely on academic potential. The admissions committee is insensitive and unashamedly 'favors' a specific group 
disregarding merit. Worse yet, what is depressing and insulting is the TPLF is giving out regularly pocket money to members of its own groups. That is poor taxpayers' money. (Bekalu)

Belgium is another destination for Tigrean guest students en masse. The site is the University of Leuven. The University of Leuven has been a center of learning for almost six centuries. Today, it is Belgium's largest and highest-ranked university as well as one of the most renowned universities in Europe. As a leading European research university, KU Leuven offers a wide variety of programmes in English. There is a special collaboration between the Mekelle institute of Technology and Leuven University (Campus Group T Leuven). A well- placed and well-informed respondent expressed:

It is true that the Mekelle institute of Technology and Leuven University (Campus Group T Leuven) have a special collaboration coordinated by a unit... The special unit is meant to facilitate talent transfer between Ethiopian and Belgian university. The activities are run by two Tigrian personalities, Mekonnen Gebreslasie Gebrehiwot and Ataklti Weldeslassie (Ataklti Gebremehin) both from Mechanical Engineering Technology TC, Campus Group T Leuven. All the candidates are from Mekelle University. The regime is in particular keen on training/educating the Tigrean youth in technology, agriculture, engineering, and business field of studies.

The trend can be observed in tens of foreign universities in which Ethiopian students are currently being hosted. It is not hidden that the Tigray Regional Government has a special interest in expanding technology and industry in the region at any cost and is advancing that aggressively. It builds partnership abroad with a focus on engineering, sanitation, water management systems, and new technologies ${ }^{49}$. For varied structural reasons, other regions in the country lag far behind in that respect. The purpose of Mekelle Institute of Technology (MIT) is to advance this activity. The institute is a symbol of the grandiosity the regime created for the region to advance world class technology and science education with the money generated in the rest of Ethiopia. The ethnicist and exclusionist attempt by the regime to thus create group based inequalities in scholastic achievement among ethnic groups is an untenable position, not capable of being maintained or defended in the long run.

Another scenario that feeds into the situation discussed earlier is the condition of overseas scholarship opportunities for Ethiopian young graduates. Being a "developing" country, young academics often search for quality/"privileged" further educational opportunities in the "western" countries. There are various scholarship schemes that offer the possibility for Ethiopian young graduates to apply for. Some of the scholarships are obtained through merit based individual competition while others are obtained through bilateral institutional agreement. Quota Scheme is one of the scholarships that the Norwegian government offers for educational opportunities to applicants from Ethiopian universities that have collaboration agreements with Norwegian universities. A former recipient of Erasmus scholarship in Norway, and currently a researcher at a university in Sweden, indicated that the bilateral agreement scheme is highly biased and favors a particular university and students from a particular ethnic group. While sharing her experience as an international student in Norway, she expressed that "students from Tigray region takes the lion's share among those who are sent through this bilateral cooperation." (Yemisrach)

My respondent, who was a beneficiary of another scholarship scheme, has expressed her doubts if those students are offered the opportunity based on their academic merit. 
The University of Haifa, Israel, currently hosts eleven guest students from Ethiopia ${ }^{50 .}$ According to my informants from Israel, all of the students belong to one ethnic group, Tigre, and come from Qalamino Special High School .51. A few years ago another group of students solely from one ethnic group have been trained in the same university. According to an engineering student of Ethiopian Jewish origin:

I am studying Engineering at the university. I have seen exclusively Tigrean students at the camp since about two years ago. I did not talk to them at length except some sporadic greetings. Some of them are undergraduate students. Some pursue a higher degree. They study civil engineering and irrigation. I think all of them came from Qalamino Special High School52. I am familiar with the school. All the students are exclusively from Tigray region. They qualify to join the school with special secondary school entrance exams. The elites boast that the future leaders of Ethiopian people will emerge out of this school. The students are smart. No question about their future success in advanced education because the precondition in the school is superb. Attending this school sets students up for life long success. They seem to be doing very well at The University of Haifa.

Going to a top boarding school as in Qalamino Special High School can do more than help students get into top colleges, it can provide them with a powerful alumni network, ethnic superiority, a solid education, and lifelong friends with similar mentality. Here we see the ethnic affiliation being converted into a social, economic, cultural and symbolic capital.

The French sociologist and public intellectual Pierre Bourdieu has argued that it is the culture (the ideology) of the dominant group(s) - the group(s) that control the economic, social, and political resources - that is embodied in the schools, and that it is this embodiment that works as a reproduction strategy for the dominant group. Therefore, poor achievement for some (ethnic) groups in a society and success for others is not something inherent in cultural difference per se, but is an artifact of the way schools operate. Those with the appropriate cultural capital [in the Ethiopian case, both appropriate social and cultural capital and belonging to the right ethnic groups apply] are reinforced with success while others are not (Bourdieu \& Passeron, 1977; Bourdieu, 1986, 1988). Michael Foucault also analyzed how educational institutions are subject to discourse and how they control the access of individuals to various kinds of discourse (references cited in Berhanu, 2011).

When political or legal institutions that are in place in Ethiopia fail to protect individuals' fundamental rights and liberties, members of the unjustly treated groups, in this case the great majority of Ethiopians, feel disempowered in particular in the intellectual sphere and educational opportunities. They are likely to view the institutions that impose such conditions as unjust, and thus find themselves in the midst of a justice conflict. If the subordinate group believes that it lacks the power to change things through political or diplomatic means, it may conclude that the only effective way to pursue justice is through violent confrontation. ${ }^{53}$. That is where Ethiopia currently finds itself; in an intractable conflict (not easily controlled). I fear that this is going to cost a lot unless the current so-called leaders change their policy of Ethnic apartheid. As Al Arabia English ${ }^{54}$. recently reported, the country's future depends on the government's ability to implement real federalism, integrate each community, and distribute the fruits of growth. If it is unwilling or unable to do so, the possibility of large-scale civil and ethnic conflict can no longer be discarded.

\section{A Self-Fulfilling Prophesy and the So-Called Matthew Effect}

It is obvious that the haves are in an advantageous position to perform better and excel in many ways and fields. The so-called Matthew effect is relevant here. In his recent book 
Gladwell (2008) argues that people do not just happen to become successful. A long line of support systems including cultural legacies, familial, and a lot of other background factors play a crucial role. Selection, streaming, and differentiated experience are also important factors. The best example of this is the experience of hockey players in Canada:

The way Canadians select hockey players is a beautiful example of what the sociologist Robert Merton famously called a self-fulfilling prophesy, a situation in which a self-definition in the beginning evokes a new behavior that makes the original false conception come true. Canadians start with a false definition of who the best 9- and 10-year-old hockey players are. They are just picking the oldest every year. But the way they treat those all-stars ends up making their original false judgement look correct. As Merton puts it, "This specious validity of the self-fulfilling prophesy perpetuates a reign of error for the prophet will cite the actual course of events as proof that he was right from the very beginning (Gladwell, 2008, p. 33). ${ }^{55}$.

This is also true at group (e.g., ethnic and sex groups) and nation levels. A good example is the phenomenon of what psychologists call stereotype threat. Members of stigmatized groups lag behind others partly because they have internalized the stereotypes. Some minorities do worse in academic and other settings merely because they expect to do worse. Their negative expectations produce stress and interfere with cognition. It is not only blacks in western countries, but also girls, disabled persons, and even older people who can also become victims of their own low expectations (Time, 2009, June 1) ${ }^{56}$. Unfortunately, signs of these malaises and disorder are already observed in Ethiopia. During my brief visits in Ethiopia in 2015 I raised these questions with ordinary people and my observation then was that many feel dissatisfied or unhappy with their life but feel unable to change their situation, usually because they do not seem to realize the magnitude or systemic nature of the problem that is a deep and deadly vice. That is state-orchestrated intellectual genocide. These are subtle devastating mechanisms for a people to feel victims of their own low expectations.

Almost two centuries ago, the British novelist Charlotte Brontë, whose novels have become standards of English literature, succinctly captured what I will try to narrate not only in this article but also in forthcoming articles of similar nature as this is a project in the making. "Your god, sir, is the World. In my eyes, you, too, if not an infidel, are an idolater. I conceive that you ignorantly worship: in all things you appear to me too superstitious. Sir, your god, your great Bel, your fish-tailed Dagon, rises before me as a demon. You, and such as you, have raised him to a throne, put on him a crown, given him a sceptre. Behold how hideously he governs! See him busied at the work he likes best -- making marriages. He binds the young to the old, the strong to the imbecile. He stretches out the arm of Mezentius and fetters the dead to the living. In his realm there is hatred -- secret hatred: there is disgust -- unspoken disgust: there is treachery -- family treachery: there is vice -- deep, deadly, domestic vice. In his dominions, children grow unloving between parents who have never loved: infants are nursed on deception from their very birth: they are reared in an atmosphere corrupt with lies ... All that surrounds him hastens to decay: all declines and degenerates under his sceptre. Your god is a masked Death." - Charlotte Brontë, Shirley.

For two decades or so I have been engaged in discussions of equity issues in the field of special education. My general areas of research interest are race, ethnicity, and special education. Of particular interest to me is "group-based inequalities" in scholastic achievement and minority students' learning and development in a globalized and post-colonial world. How people view phenomena such as inclusion-exclusion and normality-deviation in the research field of special education is an area that is of great interest to me and can easily be tied into my own field of 
research. Surprisingly, I have been oblivious or unsuspecting and ignorant of what happened in my own country in terms of intellectual spheres.

It is to be remembered that some years ago I reviewed ${ }^{57 .}$ (Berhanu, 2007) the controversial book IQ and the Wealth of Nations, written by Richard Lynn and Tatu Vanhanen. I critiqued the authors' major assertion that a significant part of the gap between rich and poor countries is due to differences in national intelligence. The authors claim that they have evidence that differences in national IQ account for substantial variation in per capita income and growth of a nation. This essay review debunks their assumptions that intellectual and income differences between nations stem from genetic differences. This critique provides an extended review of the research literature that argues against these assumptions and presents a different picture from that presented by Lynn and Vanhanen about the concept of intelligence, what IQ measures and does not measure. The essay exposes the racist, sexist, and antihuman nature of the research tradition in which the authors anchored their studies and the deep methodological flaws and theoretical assumptions that appear in their book. The low standards of scholarship evident in the book render it largely irrelevant for modern science. This essay specifically deals with the IQ value of Ethiopian immigrants that came from Israel, used by the authors as representing the National Average IQ of Ethiopia. Most of these immigrants had rudimentary knowledge of literacy, and experienced an abrupt transition from rural Ethiopia to Israel, with all the accompanying effects that it entails such as trauma, dislocation, and cultural shock. The test was conducted a few months after their arrival. That specific study, conducted by two Israelis, which assigns low IQ to the immigrants, is also replete with technical and statistical errors. One might arrive at the conclusion that further action of a legal nature would be necessary to put an end to such postulations, which in my view do not bear scrutiny.

Note that this same IQ datum (63) has been used (as third-hand information) in a controversial article in the November issue of the British Journal of Health Psychology by Satoshi Kanazawa (2006) in which the author confidently stated that low IQ levels (rather than inequality, poverty, and disease) are the reason for African nations' chronic ill-health, high infant mortality rate, and low life-expectancy. Kanazawa (2006) claims that he reached this conclusion by comparing national IQs with indicators of ill health in 126 countries. That same IQ datum has again been used in Kanazawa's article and Lynn's book (which were the subject of my review in Academic Racism: Lynn's and Kanazawa's Ill-Considered Theory of Racial Differences in Intelligence ${ }^{58}$ ) to make further untenable and unscientific assumptions. Here I critiqued and explicated these flawed assumptions, questionable data, inappropriate analyses, and highly biased interpretations. In my entire academic career, I have never come across a scholastic work that is so replete with fundamental and substantive analytical, theoretical, and methodological flaws. I hope my essay review highlighted this point.

The reason I raised this matter is because while I was busy dismantling the tenets of these scholars, my home land is busy with divide-and-rule games and portraying one ethnic group as "gold," as "chosen," and as the rightful master of the nation. This nonsense politics reminds me of what we educators call The Pygmalion effect, or Rosenthal effect ${ }^{59}$. The Pygmalion effect, or Rosenthal effect, is the phenomenon whereby higher expectations lead to an increase in performance. The effect is named after the Greek myth of Pygmalion, a sculptor who fell in love with a statue he had carved, or alternately, after the Rosenthal-Jacobson study (Rosenthal \& Jacobson, 1992). A corollary of the Pygmalion effect is the golem effect ${ }^{60}$, in which low expectations lead to a decrease in performance; both effects are forms of self-fulfilling prophecy. By the Pygmalion effect, people internalize their positive labels, and those with positive labels succeed accordingly. The idea behind the Pygmalion effect is that increasing the 
leader's expectation of the follower's performance will result in better follower performance. Within sociology, the effect is often cited with regard to education and social class ${ }^{61}$. (see Birku, 2016, for a critical comparison based on data from Ethiopia ${ }^{62}$.).

In the Ethiopian context we can relate it to the psychological phenomenon in which lower expectations placed upon individuals of ordinary citizens or those who belong to "the wrong ethnic groups" either by the political elites, managers, the new rich or the Tigreans. This effect is mostly seen and studied in educational and organizational environments which I plan to delve into in my future work. It is a form of self-fulfilling prophecy. The only thing the rulers have for now is abundant possessions of the material wealth illegally gained, which I fear is in the process of being used to create group based inequalities in scholastic achievement. The information/data gathered and presented here and facts documented elsewhere testify to the fact that intellectual genocide is already in the making. Dimetros Birku (August 26, 2016) outlined what the Tigreans should realize sooner than later. Worrisome in all this is that neither TPLF nor its base in Tigray seem to get the point that Ethiopians no longer accept any form of Tigraian chauvinism and exclusive privilege on the basis of Tigrean identity at the expense of the rest of Ethiopia. The way forward for Tigrean to reverse hate, and save themselves, is by making an informed choice between supporting Ethiopians' quest for freedom from TPLF brutal repression and TPLF. They need to weigh the matter with accuracy as to which one is in the long term interest of Tigreans ${ }^{63}$. For antithesis, see Hanesey Kedusey (Tigrai Online, June 1, 2015): Tigreans are not "Silent", but chauvinists chose not to hear them). ${ }^{64}$.

\section{A Systemic Attack on Academic Community, Distinguished Scholars and Intellectualization}

For years I have been hearing rumors that there have been discriminatory practices with regard to higher education opportunities, scholarship grants, and investment on a specific ethnic group at the expense of members of other ethnic groups. I was nonetheless unaware of the extent of the discourse of denigration and the creation of "Other." 65 . I know that bright intellectuals of other ethnic groups, in particular those who belong to the Amhara ethnic group as well as other groups and perceived as solidly intellectual with full integrities and unconditional love of their country, have been summarily dismissed from their research and teaching positions. That measure has continued as a common practice if the scholar or for that matter a journalist expresses dissent or opinions that are not agreeable to the rulers. Detention of, discrimination against, or threats or use of violence and harassment, including persecution and intimidation, directed at intellectuals and journalists (in particular members of other ethnic groups) seeking to exercise or to promote the exercise of the right to freedom of opinion and expression is a very common practice during the regime's years. A very recent example is the dismissal of two notable scholars of the Addis Ababa University, Dr. Merera Gudina and Dr. Dagnachew Assefa, the former, a prominent opposition political figure currently in jail, has been teaching at Addis Ababa University for several decades while the latter, a vocal critique of the regime in the public square, is a returnee from the United States of America and has been teaching at the same university for many years. These two scholars symbolize what it means to be intellectual in their own individual ways (see Tadeos Daniel, 2015). An article by Tadeos Daniel, The 'De-intellectualization' of Addis Ababa University and Beyond ${ }^{66 .}$ tells it all.

It is worrisome how the new and the next generation will cope with managing the country, considering that they are being stuffed or crammed with inaccurate knowledge content and a distorted curriculum. Higher education in Ethiopia leaves much to be desired. Some of them have a chronic lack of academic freedom and autonomy; are unskilled lecturers; possess an 
acute lack of learning and teaching materials; have problems related to Electronic Information Resources Awareness, Attitude and Use by academic staff members. In his book, Education in Ethiopia: From Crisis to Brink of Collapse, Professor Tekeste Negash (2006) ${ }^{67}$. has outlined major problems that beset the Ethiopian education system. The main focus of the book is the deepening crisis of the Ethiopian education system. It reconstructs the growth of the crisis of the sector during the last four decades. It then discusses the implications of the crisis in terms of communication breakdown; absence of analytical capacity at the system level; the fragmentation of society; loss of political legitimacy and perpetuation of authoritarian power. Although the education sector has greatly expanded its impact on poverty, alleviation has so far been insignificant. The poverty landscape has changed to the worse during the last 50 years. This is largely due to the fact that the Ethiopian education system is based on false premises. All these give credence to my account that it is intellectual genocide in the making, although the author has some disputes with me regarding the theme of my work here (E-mail communication, 2017-02-04 09:18).

Similarly, the gravity of the problem with respect to "massification" of higher education has been captured in a recent article by Alem Mamo entitled The Disgraceful State of Higher Education in Ethiopia: How TPLF/EPRDF Killed Higher Learning (ecadforum, April 12, 2014)68:

'Massification' of higher learning in Ethiopia, preferring quantity of graduates to quality, has reached a critical stage, and it is becoming very problematic to use the term 'university' to describe these diploma mills. In TPLF/EPRDF's Ethiopia every institution is forced to be subordinate to the twisted ideology of the regime. The first and foremost pillar of a university anywhere in the world is autonomy and academic freedom. These two elements are the oxygen of a free learning and teaching environment. Contrary to this the ruling group maintains full control over these institutions depriving them the oxygen of freedom they desperately need to breath and function freely.

The overall decline of the quality of higher learning in Ethiopia is evident in the African and world university rankings. Currently, according to the African Economist University Rankings, only one university out of 35 so-called universities in Ethiopia appears on the ranking chart ${ }^{69}$. The rest are nowhere to be seen on any of university rankings ${ }^{70}$.

Human Rights Watch $(2003,2017)^{71}$. reported the dangers of engaging in critical thinking and intellectual pursuit for truth in Ethiopia. Being educated can be a risky business in Ethiopia. Students and teachers, often among the most politically active elements of society, are frequent victims of human rights violations, including extrajudicial killings, arbitrary arrest, and denial of freedom of association and expression. Ethiopian leaders since Haile Selassie have targeted the academic community; the current government's continuation of such abusive practices emphasizes the serious obstacles facing Ethiopia before basic rights are respected and enforced not only on university campuses but across the country. According to reliable personal accounts and independent scholars, the situation has gotten worse and the country is in serious trouble, a cancerous one (see Clapham, 2009; Aalen \& Tronvoll, 2016; Abbink, 2011; Human Rights Watch, 201772.; see also Professor Alemayehu G. Mariam's extensive commentaries on the matter that spans ca 25 years; Alemayehu teaches political science at California State University, San Bernardino ${ }^{73}$.).

The Human rights Watch's report focuses on three major abuses: repeated, unjustified use of lethal force by security forces to put down political protests by students; continued repression of the independent Ethiopian Teachers' Association, whose members include many of 
Ethiopia's most distinguished professors; and the stifling of independent thought through denial of university autonomy and government control of activities on university campuses. The government of Ethiopia, the ruling party of which has its roots in a student movement, has repeatedly failed to hold those responsible for these violations accountable. The Ethiopian government has long enjoyed substantial international backing in spite of its human rights record (see also Daniel, 2015).

Over the last 12 months we are witnessing deadly protests that have rocked Ethiopia. "A year after these deadly protests began, tensions in Ethiopia remain high and the human rights situation dire, with mass arrests, internet shutdowns, and sporadic clashes between the security forces and local communities, especially in the north of the country," said Michelle Kagari, Amnesty International's Deputy Regional Director for East Africa, the Horn and the Great Lakes ${ }^{74}$. "It's high time the Ethiopian authorities stopped paying lip service to reform and instead took concrete steps to embrace it, including by releasing the myriad political prisoners it is holding merely for expressing their opinions. They should also repeal the repressive laws that imprisoned them in the first place, including the draconian Anti-Terrorism Proclamation that has also contributed to the unrest ${ }^{75}$." If these problems are not addressed seriously and instantly, or if we fail to bring about meaningful transformation in all aspects of life in Ethiopia, the current political turbulence, economic instability, and social upheaval including a risk for civil war may create a situation of a fait accompli or presumably irreversible quagmire. I very much hope that Ethiopians are clever enough to pull themselves out of this difficult, precarious, and entrapping historical position.

\section{Ethnic Identity and Ethnic Manipulation: Collective Guilt Versus Individual Responsibility}

As I mentioned earlier, I do not wish to delve into the details of material resource abuses, economic inequalities, corruption, military aspects, and political and institutional intransigencies/malfunctions. I can only critically discern the overall situation prevailing in the country as "perplexing colonialism" spearheaded by the TPLF. The rulers and their allies are supposed to be Ethiopians by "standard measures." However, most measures they take are uncharacteristic of being Ethiopian in the true sense. I presume the final goal of their measures is successively to build up "a greater Tigray" carved out of "proper Tigray" and the rest of Ethiopia in a bizarre redrawing of the country's natural borders. At the time of writing this paper a leaked legislative document shows Oromia region is pushing for extensive rights in the capital city Addis Ababa. The draft proclamation to determine Oromia's special interest in Addis Ababa contains tens of measures. Here are just a few examples: the official name of the city shall be Finfine; Afaan Oromo shall become "the working and official language" of Addis Ababa along with Amharic; Oromo residents of the city shall be entitled to the right to selfdetermination; Oromia government and Oromo residents in the city shall have priority right to use "public squares, centers, halls, stadiums, etc."; the city boundary shall be determined by a mutual agreement of the city administration and Oromia state government ${ }^{76}$. One wonders why now? What is the overall intention? Why not focus on policies and expectations that serve the interests of all ethnic groups, irrespective of their differences? In Quartz africa, Gardner (July 06, 2017) maintained that 'nine months into a state-of-emergency imposed to quell popular unrest, Ethiopia's ruling party, the Ethiopian People's Revolutionary Democratic Front (EPRDF), has unveiled its first significant political concession. But the furor surrounding the draft bill presented to parliament last week reveals just how deep tensions in Africa's second most populous country still run. At stake is the answer to a highly charged question: who owns Addis Ababa?'77. Obviously, this piece of legislation requires thorough analysis. A person without professional or specialized knowledge in the field can discern the intention of the 
regime, though. Ironically, this draft bill framed in the name of restoring justice is in fact a recipe for cultural genocide.

Divide-and-rule strategies and discourses of superiority have dangerous consequences sooner or later. A number of Ethiopian scholars I informally interviewed told me that the discourses in the power corridor, in some government affiliated social media and among adherent supporters of the regime, are characterized by a steady stream of derogatory remarks about the Oromo and Amhara ethnic groups. Some of these remarks are retardates, feeble minded, cowardice and invertebracy (the state or quality of being without a backbone, hence, metaphorically, spinelessness). These are derogatory and disparaging terms expressed in a spiteful tone (see for a further analysis and evidence Professor Alemayehu Gebre Mariam's recent article: Ethiopia: Rise of the "Amhara Retards" and Oromo "Criminals and Terrorists" in 2016?78. I actually witnessed some of these remarks hurled at me personally in an argument with ardent supporters of the TPLF at a pub in Sweden. These race linked pejoratives, expressing contempt or disapproval are a recipe for a long and protracted hatred. "Those who do not learn history are doomed to repeat it." The quote is most likely due to George Santayana, and in its original form it read, "Those who cannot remember the past are condemned to repeat it." The phrasing itself certainly is catchy. It's a big one, not only because it is so common, but also because if it is true and if history is ugly (hint: it is), then this saying ought to guide our public and private policy. It's hard to disagree with. Over our history, wars ended with confiscatory terms of surrender inevitably breed more wars. Revolutions that give an individual absolute power inevitably end up as brutal dictatorships. Even individuals are subject to this advice. Couples who do not learn from their fights break up. People who don't learn from their mistakes don't mature, ${ }^{79}$.

All this government orchestrated propaganda and a culture of belittling other ethnic groups will backfire. We should learn from history! The colonial changes to ethnic identity have been explored from the political, sociological, and psychological perspectives ${ }^{80}$. Ethnic manipulation manifested itself beyond the personal and internal spheres. Scott Straus from the University of Wisconsin describes the ethnic identities that partially contributed to the Rwandan genocide. In April 1994, following the assassination of Rwanda's President Juvénal Habyarimana, Hutus of Rwanda turned on their Tutsi neighbors and slaughtered between 500,000 and 800,000 people in just 100 days. While this situation was incredibly complex politically, the influence ethnicity had on the violence cannot be ignored. Before the German colonization of Rwanda, the identities of Hutu and Tutsi were not fixed. Germany ruled Rwanda through the Tutsi dominated monarchy and the Belgians continued this following their takeover. Belgian rule reinforced the difference between Tutsi and Hutu. Tutsis were deemed superior and were propped up as a ruling minority supported by the Belgians, while the Hutu were systematically repressed. The country's power later dramatically shifted following the so-called Hutu Revolution, during which Rwanda gained independence from their colonizers and formed a new Hutu-dominated government. Deep-seated ethnic tensions did not leave with the Belgians. Instead, the new government reinforced the cleavage ${ }^{81 .}$.

In his fascinating analysis of the root causes of ethnic based-genocide Straus (2006) wrote, "Ethnic antipathy might drive one perpetrator, while fear may drive another, even if both participate in the same genocide. Obedience Olay have led a person to kill the first time, but thereafter he might have wanted to steal goods or he might have become acculturated to killing. In short, motivation-the mechanism driving individuals-can be both heterogeneous within individuals as well as among them, even during a single event (p. 39)". The main point, however, is that we do not know which variables and mechanisms drove the Rwandan genocide. Many of the above hypotheses are plausible, wrote Straus. What we learn from this 
experience is that demonizing other ethnic groups or creating a discourse of inferior or superior is a recipe for genocide. One well-documented ethnic manipulation is the ruling elites' vicious acts of fomenting conflict between the two large ethnic groups, the Oromos and the Amharas. It is to be noted that in this state-orchestrated act, the Amharas are the primary victims. This all created a sense of ontological insecurity for the Amhara poor. The conflicts caused not only causalities and migration/movement within national borders but also contributed vastly to the spread of disease, malnutrition, starvation, social and economic decline and moral deterioration ${ }^{82}$.

Clearly the responsibility lies with the elites. Fearon and Laitin (2000) found considerable evidence linking strategic aspects of ethnic identity construction to violence and more limited evidence implicating discursive systems ${ }^{83}$. The most common narrative in these texts analyzed by the authors has largescale ethnic violence provoked by elites, often motivated by intraethnic conflicts. Followers follow, despite the costs, out of increased fear of thugs and armies "let go" by elites (both the other side's and their "own") and often in pursuit of local grievances that may have little ethnic component. Several other mechanisms are also discussed, including the role of discursive systems in conditioning publics for violence and the role of violent efforts to enforce "everyday primordialism" by policing supposedly primordial ethnic boundaries ${ }^{84 .}$

The noted political scientist, Hannah Arendt, whose book Eichmann in Jerusalem: A Report on the Banality of Evil 85 , caused heated controversy throughout the intellectual world, wrote on "Personal Responsibility Under Dictatorship." That specific book and a number of her articles on The New Yorker dwell on the topic from a philosophical perspective. Hannah Arendt referred to the post-war climate in Germany--where those personally innocent during the Nazi period all admitted to their "collective guilt" while the real criminals showed no remorse as "the quintessence of moral confusion."(Arendt, 1987). The concept of collective guilt, as opposed to individual guilt, is "senseless," Mrs. Arendt said, and only serves as an effective "whitewash" for guilty individuals to hide behind ${ }^{86 .}$. I raise this point because I would like to reflect on the consciousness of the TPLF supporters including the Tigreans. I am sure all of them do not support the regime. I want to believe that they also live under fear and control. Of course there is a great deal of brainwashing. I am sure all do not benefit from the new opportunities. That is what I want to believe, although some of my respondents tell me different discourses. However, my position is that it is not right to collectively blame an entire group because members of the group commit genocide or massacre or show indifference to the plight of others. Legal analysts and philosophers still argue about the phenomenon of collective guilt. The English dictionary defines collective guilt as defining guilt that is shared by a group of people over an act or actions that are seen as shameful. It is not talked about, but does manifest. For instance, Afrikaners of South Africa have a collective guilt over Apartheid. So do the Germans on the Holocaust. In this regard it is probably high time to hear voices, Not In My Name ${ }^{87}$. from the ethnic Tigreans.

The phenomenon of collective responsibility ${ }^{88}$. also known as collective guilt is highly a contentious matter in the Ethiopian context. Are the Tigreans responsible for the actions of TPLF; by tolerating, ignoring, or harboring them, or actively collaborating in these actions? The practice of blaming the Jews for Jesus' death is the longest example of collective responsibility. In this case, the blame was cast not only on the Jews of the time but upon successive generations. This comes from Matthew 27:25-66 New International Version (NIV) 25: "All the people answered, 'His blood is on us and on our children!'". This collectivist idea that groups of humans can bear guilt above and beyond the guilt of individual members, and hence individuals hold responsibility for what other members of their group have done, even if they 
themselves didn't do this, is in my view problematic. ${ }^{89}$. However, at least a symbolic resistance or some form of manifestation is morally expected from the Tigran people and their civil societies because the crime is being committed in their names. If they do not ally with oppressed segments of the Ethiopian population, history will judge them. One expects some form of dissent or disagreement with the methods, goals, and policies of the political party and government.

\section{SUMMARY AND THE ROAD FORWARD}

In this thesis, my overarching investigatory theme has been intellectual genocide operationally defined as three pronged that is firstly structural and systematic discriminations favoring a specific ethnic group with regard to educational opportunities, higher education and scholarship grants. In short a system of streaming, tracking and differentiation which favours the haves, the elites, and the favoured ethnic group in some subtle structurally embedded manners. According to the information or reports that are available, or from peoples' accounts, higher educational opportunities, in particular scholarships abroad, appear to be distributed unevenly along ethnic lines. The degree of educational inequality is associated with the ethnic structure of the national education system. In addition, rigid systems with dead-end educational pathways appear to be a hindrance to the equalization of educational opportunities, especially if the sorting and national assessments of students occur early in the educational career. Secondly, the term refers to brain draining (i.e., the movement of intellectuals and young skilled Ethiopians) has increased under the TPLF regime. Some observers say that Ethiopia has become a substantial net exporter of academic talent, a "brain drain." Thirdly the term refers to cultural genocide, the action of the system which has the aim or effect of dispossessing the people of their lands, territories, or resources, cultural values, language and historical/religious relics, and heritages.

Along these three lines I tried to collate evidences and outline my and others' critical and reflective accounts. My strong recommendation is that it is high time to stop the madness and redress the chronic and pervasive disparities within and between groups. It is an imperative that we focus on our similarities and common destiny. Because "the basis of democratic development is therefore the demand for equality, the demand that the system of power be erected upon the similarities and not the differences between men [sic]" (Laski, 1965:10). It is still in our capacity to revert this "monstrous racial ideology"90. Historians have written of a number of reasons or mechanisms that lead from ethnicity to violence. According to Straus (2006: 36) one is dehumanization. Whether because of prejudice or ideological indoctrination, individuals may degrade people in a different ethnic category; such degradation in turn facilitates violence. Another mechanism is antipathy: individuals commit crime because they distrust or abhor members of another ethnic category. A third mechanism is ideological commitment: individuals commit violence because of their strong political beliefs and desires. A fourth mechanism concerns media effects, in particular how propaganda indirectly or directly conditions people to kill. Some claim that propaganda "instills" dehumanizing stereotypes of ethnic others; still others claim that the propaganda "brainwashes" the perpetrators. My evidence shows that there are already some patterns and discourses that might precipitate or crystallize the above mechanisms in Ethiopia.

This is a wakeup call for the Tigreans as these are matters of very real and growing concern to people living in Ethiopia and beyond. Nonetheless, all Tigreans should not be held collectively responsible for the crimes of their elites. They have, however, a moral responsibility. The key components of the basic notion of moral responsibility, as David Risser accurately captured, are deeply rooted in the fabric of every society and are constitutive of social life. Without some conception of moral responsibility no amount of imaginative insight will render a society 
recognizable as a human society. While there is broad, often tacit, agreement regarding the basic model of moral responsibility as it applies to individuals, there is considerable debate about how this notion might be applied to groups and their members ${ }^{91}$.

"The fight is never about grapes or lettuce. It is always about people." It is about Ethiopian people. It is unacceptable to seek self-aggrandizement for ourselves or for our specific ethnic group and increase power and influence to draw attention to own importance- and forget about progress and prosperity for the multitudes of ethnic groups in Ethiopia. Our ambitions must be broad enough to include the aspirations and needs of others, for their sakes and for our own.

For now the communication - conflict and tension - between the political elites and the masses of Ethiopia appears to have reached an impasse. I read somewhere in Amharic that "with every new decree, tragedy of the dissident elite of Ethiopia widens, deepens, as it also exposes the underlying intention of those who hold power: to maximize efforts for a 'negative selection' as it happened once upon a time in Germany. Decree after decree, what we observe is the victory of intolerant mediocrity and ethno-nationalization over hard-earned merit, and civil courage."

The only way out of this quagmire and stalemate is the establishment of an all-inclusive government which guarantees freedom, justice, and democratic accountability. As George Orwell (1949) wrote in his acclaimed novel Nineteen Eighty-Four ${ }^{92}$. that It was possible, no doubt, to imagine a society in which wealth, in the sense of personal possessions and luxuries, should be evenly distributed, while power remained in the hands of a small privileged caste. But in practice such a society could not long remain stable. For if leisure and security were enjoyed by all alike, the great mass of human beings who are normally stupefied by poverty would become literate and would learn to think for themselves; and when once they had done this, they would sooner or later realize that the privileged minority had no function, and they would sweep it away. In the long run, a hierarchical society was only possible on a basis of poverty and ignorance'93. Clapham (2011: 191) succinctly stated that "the deeper problem facing Ethiopia is that it is now too complex and diverse a society to be managed without the extremely adept deployment of the political skills - of discussion, bargaining, compromise and simultaneous recognition of alternative sources of authority - that are needed to create some kind of workable synthesis of the different elements of which it is composed. Regardless of the immediate ability of the government to maintain itself in power by force, this is not a viable option for long-term governance".

I would like to close my thesis with the following quotation by Cesar Chavez, labor leader and civil rights activist, from his address to the Commonwealth Club on November 9, 1984:

Once social change begins it cannot be reversed. You cannot uneducate the person who has learned to read. You cannot humiliate the person who feels pride. You cannot oppress the people who are not afraid anymore.

\section{Reference}

1. TPLF is the main and most powerful party within the Ethiopian People's Revolutionary Democratic Front, the so called ruling political coalition which consists of four political parties. The TPLF-backed Ethiopian People's Revolutionary Democratic Front took power after the collapse of the Derg in 1991.

2. Lovise Aalen \& Kjetil Tronvoll (2009) The End of Democracy? Curtailing Political and Civil Rights in Ethiopia, Review of African Political Economy, 36:120, 193-207, DOI: 
10.1080/03056240903065067.

3. Arriola, Leonardo R. \& Terrence Lyons. 2016. “Ethiopia: The 100\% Election.” Journal of Democracy 27, 1 (2016): 76-88.

4. Is Africa's rising power on the brink of collapse? Remi Benoit Piet, Special to Al Arabiya English. Thursday, 25 August 2016.https://english.alarabiya.net/en/perspective/analysis/2016/08/25/Is-Africa-s-rising-power-onthe-brink-of-collapse-html.

5. Discontent grows louder in Ethiopia as regime fights for survival (The Financial Times Dec. 2016)

6. The Guardian. Ethnic tensions in Gondar reflect the toxic nature of Ethiopian politics. William Davison in Gondar. Thursday 22 December 2016 12.17 GMT.

7. Jon Abbink (2011) Ethnic-based federalism and ethnicity in Ethiopia: reassessing the experiment after 20 years, Journal of Eastern African Studies, 5:4, 596-618, DOI: 10.1080/17531055.2011.642516.

8. Christopher Clapham (2009) Post-war Ethiopia: The Trajectories of Crisis, Review of African Political Economy, 36:120, 181-192, DOI: 10.1080/03056240903064953.

9. Arriola, Leonardo R. 2013. "Protesting and Policing in a Multiethnic Authoritarian State: Evidence from Ethiopia." Comparative Politics 45, 2 (2013): 147-168.

10. http://www.businessinsider.com/legatum-institute-prosperity-index-2015-worst-countries-2016$1 /$ ?r=UK\&IR=T\&IR=T/\#30-zambia--zambians-enjoy-pretty-good-levels-of-social-capital-governance-andpersonal-freedom-but-only-six-countries-in-the-whole-prosperity-index-scored-worse-when-it-comes-to-healththis-helped-push-the-country-down-the-rankings-and-onto-this-list-2

11. Mark Tran, "Ethiopia's renaissance under Meles Zenawi tainted by authoritarianism," The Guardian: Poverty Matters Blog (Aug. 2012).

12. International Peace Institute. Global Observatory. https://theglobalobservatory.org/2016/09/ethiopiaprotests-amhara-oromiya/

13. https://www.washingtonpost.com/news/worldviews/wp/2017/03/15/ethiopia-boasts-about-its-economicprogress-the-body-count-at-a-garbage-dump-tells-another-story/?utm_term=.fb23fa271157

14. Negash, Assefa (1996). The pillage of Ethiopia by Eritreans and their Tigrean surrogates. Los Angeles : Adey.

15. David Steinman (2017) Ethiopia's Cruel Con Game and his new book Money, Blood and Conscience https://www.moneybloodandconscience.com/ . http://www.zehabesha.com/ethiopias-cruel-con-game-davidsteinman/

16. https://www.forbes.com/sites/realspin/2017/03/03/ethiopias-cruel-con-game/\#19d3d78829d0

17. Geuss, Raymond (1981). The Idea of a Critical Theory. Cambridge: Cambridge University Press.

18. Horkheimer, Max. 1982. Critical Theory Selected Essays. New York: Continuum Pub.

19. Ellis, Carolyn, "Sociological Introspection and Emotional Experience" (1991). Communication Faculty Publications. Paper 268. http://scholarcommons.usf.edu/spe_facpub/268

20. http://www.worldbank.org/en/country/ethiopia/overview

21. Beyene, Bezawit (2011). Ethnicity, Ethnic Conflicts, and Secessionism in Ethiopian Politics Journal of Conflict Transformation \& Security, Vol. 1, No. 2, 2011.

22. Aalen, Lovise (2011). The Politics of Ethnicity in Ethiopia: Actors, Power and Mobilisation Under Ethnic Federalism. E. J. Brill Publishers.

23. Federal Ministry of Education. Education Management Information System (EMIS) and ICT Directorate. Addis Ababa, Ethiopia. Website: www.moe.gov.et. Released in 2016.

24. Robert Jaulin (1970). La paix blanche : introduction à l'ethnocide (in French). Éditions du Seuil.

25. Declaration on the Rights of Indigenous Peoples". United Nations Permanent Forum on Indigenous Issues. Retrieved 28 December 2016

26. Farkas, G. (2003). Racial disparities and discrimination in education: What do we know, how do we know it and what do we need to know? Teachers College Record, 105,1119-1146.

27. Huck, S. W. (2008) Reading statistics and research (5th ed.). Boston, MA: Pearson Education, Inc. 
28. Lemkin, Raphael. 1944. Axis Rule in Occupied Europe: Laws of Occupation-Analysis of Government-Proposals for Redress. Washington, D.C.: Carnegie Endowment for International Peace. Available online at <www.prevent genocide.org/lemkin/AxisRule1944-1.htm>

29. Chrisopoulos, Paul. J. 1995. "Giving Meaning to the Term 'Genocide' as It Applies to U.S. Immigration Policy." Loyola of Los Angeles International and Comparative Law Journal (October); Heidenrich, John G. 2001. "The Father of 'Genocide' - and Its Biggest Foe." Christian Science Monitor (June 27); Yacoubian, George S., Jr. 2003. "Evaluating the Efficacy of the International Criminal Tribunals for Rwanda and the Former Yugoslavia." World Affairs 165 (January 1).

\section{0. http://www.genocidewatch.org/genocide/whatisit.html}

31. http://nazret.com/blog/index.php/2015/03/24/ethiopia-the-de-intellectualization-of - of Addis Ababa University and beyond. Ethiopia: The 'de-intellectualization' of Addis Ababa University and beyond

32. https://www.hrw.org/reports/2003/ethiopia0103/LESSONS IN REPRESSION: VIOLATIONS OF ACADEMIC FREEDOM IN ETHIOPIA (Vol. 15, No. 2). (https://www.hrw.org/reports/2003/ethiopia0103/ethiopia010303.htm.

33. The Guardian (2015). Ethiopia's Higher Education Boom Built on Shoddy Foundations (Contributor). 22/06/15. http://www.theguardian.com/global-development-professionals-network/2015/jun/22/ethiopiahigher-eduction-universities-development. Also Esat (2014). ESAT Special Interview on Higher Education in Ethiopia and Oromo Students Movement with Paul O'Keeffe. June 2014. http://ethsat.com/video/esat-specialprogram-interview-with-paul-okeeffe-june-2014/

34. Ethiopia's higher education's strategy of growth is flawed. Rather than focusing on quality. It is obsessed in mere quantitative growth of number of universities. Post graduate students are lectured by those who don't have doctoral degree. The leaders of the country's higher learning institutes are politically appointed. How can you expect quality and excellence when you have leaders who are appointed by their mere loyalty to the ruling party?! Interview with Paul O'Keefe. (https://www.youtube.com/watch?v=eLa4PKwAtjI)

35. https://www.nazret.com/2017/06/26/the-cruel-political-jokes-of-the-t-tplf-in-ethiopia/

36. Beyene, Bezawit (2011). Ethnicity, Ethnic Conflicts, and Secessionism in Ethiopian Politics Journal of Conflict Transformation \& Security, Vol. 1, No. 2, 2011.

37. Miller, Joshua and Schamess, Gerald (2000) "The Discourse of Denigration and the Creation of "Other"," The Journal of Sociology \& Social Welfare: Vol. 27 : Iss. 3 , Article 4. Available at: http://scholarworks.wmich.edu/jssw/vol27/iss3/4.

38. Ajala, OA and K Asres, K. (2008). Accessibility In equality to Basic Education in Amhara Region, Ethiopia, Ethiopian Journal of Education and Sciences, Vol 3, No 2 (2008)

39. https://www.theguardian.com/global-development-professionals-network/2015/jun/22/ethiopia-highereduction-universities-development. Monday 22 June 2015 15.16 BST Last modified on Wednesday 31 May 2017 11.13 BST.

40. Ethiopia's higher education's strategy of growth is flawed. Rather than focusing on quality. It is obsessed in mere quantitative growth of number of universities. Post graduate students are lectured by those who don't have doctoral degree. The leaders of the country's higher learning institutes are politically appointed. How can you expect quality and excellence when you have leaders who are appointed by their mere loyalty to the ruling party?! Interview with Paul O'Keefe. Publicerades den 22 aug. 2015. (https://www.youtube.com/watch?v=eLa4PKwAtjI)

41. Swartz, D. (1997). Culture \& power: the sociology of Pierre Bourdieu. University of Chicago Press.

42. Bourdieu, P. (1991). Language and symbolic power. Cambridge: Polity Press.

43. Portes, A. (1998). 'Social Capital: Its Origins and Applications in Modern Sociology,' in Annual Review of

Sociology 24, 1-24.

44. Central Statistical Agency [Ethiopia] and ICF International. 2012. Ethiopia Demographic and Health Survey 2011. Addis Ababa, Ethiopia and Calverton, Maryland, USA: Central Statistical Agency and ICF International. (p. 27)

45. http://ethioforum.org/ethiopia-crises-force-millions-out-of-school/ 
46. EDHS (2011) Central Statistical Agency [Ethiopia] and ICF International. 2012. Ethiopia Demographic and Health Survey 2011. Addis Ababa, Ethiopia and Calverton, Maryland, USA: Central Statistical Agency and ICF International.

47. Regional and gender differences in academic achievement as a function of opportunities to learn (OTL). Melaku Tesema, Johan Braeken, Jan-Eric Gustafsson. JOINT CONFERENCE OF THE EARLI SPECIAL INTEREST GROUPS 18 (Educational Effectiveness) and 23 (Educational Evaluation, Accountability and School Improvement). CONFERENCE PROCEEDINGS. 28-30 SEPTEMBER 2016 - UNIVERSITY OF OSLO

48. http://ethioforum.org/out-of-55-scholarship-students-50-are-tigrean/

49. https://www.nazret.com/2017/06/22/land-restoration-in-ethiopia-this-place-was-abandoned-this-isincredible-to-me/ June 22, 2017 by Cathy Watson.

50. https://www.facebook.com/channelietv/videos/1027275037377041/.

51. http://www.mitethiopia.edu.et/background/

52. https://youtu.be/Jf07EIKFhNw?t=309

53. Paul Wehr, Heidi Burgess, and Guy Burgess (1994) Justice Without Violence. Lynne Rienner Publishers, 1994), 9.

54. Remi Benoit Piet, Special to Al Arabiya English Thursday, 25 August 2016 (Is Africa's rising power on the brink of collapse?)

55. Gladwell, M. (2008). Outliers: The story of success. New York: Little, Brown.

56. Time (2009, June 1). Why your memory may not be so bad after all. New data on how internalizing stereotypes affects boomers (By John Cloud).

57. Berhanu, G. (2007). Black intellectual genocide: An essay review of IQ and the Wealth of Nations. Education Review, 10(6). Retrieved from http://edrev.asu.edu/essays/v10n6index.html.

58. Berhanu, G. (2011Nov.). Academic Racism: Richard Lynn's and Satoshi Kanazawa's bogus and sub-standard theory of racial differences in intelligence: An essay review of Racial Differences in Intelligence: An Evolutionary Analysis by Richard Lynn (2008) and a review of Temperature and Evolutionary Novelty as Forces Behind the Evolution of General Intelligence by Satoshi Kanazawa (2008) In Educational review. Volume 14, number 8. ISSN 1094-5296.

59. McNatt, D. B. (2000). "Ancient Pygmalion joins contemporary management: A meta-analysis of the result". Journal of Applied Psychology. 85 (2): 314-322. doi:10.1037/0021-9010.85.2.314. PMID 10783547

60. Oz, S. \& Eden, D. (1994). "Restraining the Golem: Boosting performance by changing the interpretation of low scores". Journal of Applied Psychology. 79 (5): 744-754. doi:10.1037/0021-9010.79.5.744

61. Rosenthal, Robert; Jacobson, Lenore (1992). Pygmalion in the classroom (Expanded ed.). New York: Irvington.

62. TPLF created a Tigraean psychological image - one that paints Tigreans (or tegaru as they call it) as invincible, hardworking and valorous while the rest of Ethiopians are painted in light of all forms of derogatory attributes including coward. The late Meles Zenawi, for example, told a stadium full of crowed in Tigray that Tigryeasn are ( note the implied us and other here) golden people. And apparently majority of Tigreans seem to have believed the new TPLF manufactured images of themselves and other Ethiopians. Perhaps it is even possible to find a good number of Tigreans who tend to think that the world revolves around TPLF, that TPLF is benevolent and that Ethiopians owe TPLF praise and support. Also, ample circumstantial evidences seem to exist that suggest TPLF worked hard to make the rest of Ethiopians believe in the narrative but to no avail.

63. http://www.borkena.com/2016/08/26/ethiopia-the-hate-from-and-to-tigray/

64. http://www.tigraionline.com/articles/tigraian-silence-not.html

65. Miller and Schamess, Gerald (2000) "The Discourse of Denigration and the Creation of "Other","The Journal of Sociology \& Social Welfare: Vol. 27: Iss. 3, Article 4. Available at:

http://scholarworks.wmich.edu/jssw/vol27/iss3/4

66. http://nazret.com/blog/index.php/2015/03/24/ethiopia-the-de-intellectualization-of Addis Ababa University and beyond (By Tadeos Daniel).

67. Education in Ethiopia: From Crisis to Brink of Collapse (NAI Discussion Papers) Paperback - August, 2006 (by Tekeste Negash) 
68. http://ecadforum.com/2014/04/12/the-disgraceful-state-of-higher-education-in-ethiopia-how-tplfeprdfskilled-higher-learning/

69. http://theafricaneconomist.com/top-100-universities-in-africa-in-2013/\#.U0mgsSiMXzI

70. A response to Alem's article by an anonymous writer is captivating "Thank you Alem Mamo for recapitulating the total collapse of higher learning in our "Universities" and the devastating consequences on the future of our country. Sadly, the debacle is not limited to "Universities" only, but also to Colleges, High Schools, and Elementary Schools. It is from bottom up and everything sounds designed to undermine the country. The killing of higher or lower education is perfectly fitting to the agenda of woyane/TPLF. The ultimate motive is to produce cadres of all sorts and incompetent graduates in sub-standard "Universities" that serve the regime as political tools and cadres and not intellectuals of any capacity. The other motive behind the so-called "proliferation of universities" is to pillage students and parents in the form of tuition fees for just staying in empty buildings. This, of course, is an extension of the grand design of economically bleeding the country and hang onto power as long as desired. If the regime is interested in educating Ethiopians, it can make higher education standardized and produce intellectuals that are competent locally and globally. Sadly, that is not the whole purpose. The Chinese who are belittled and ridiculed by the West for everything have this wisdom/proverb to share with humanity and I quote, "When planning for a year, plant corn. When planning for a decade, plant trees. When planning for life, train and educate people" (Mario, April 13, 2014 at 12:04 am). http://ecadforum.com/2014/04/12/the-disgraceful-state-of-highereducation-in-ethiopia-how-tplfeprdfs-killed-higher-learning/

71. Lessons In Repression: Violations Of Academic Freedom In Ethiopia. http://www.refworld.org/docid/3f4f59533.html

72. World Report 2017: Our annual review of human rights around the globe. The Dangerous Rise of Populism. Global Attacks on Human Rights Values. https://www.hrw.org/world-report/2017

73. http://almariam.com/sample-page/

74. https://www.amnesty.org/en/latest/news/2016/12/ethiopia-opposition-leader-arrest-outrageous-assault/

75. Ibid.

76. http://hornaffairs.com/2017/05/01/draft-law-oromia-special-interest-addis-ababa/

77. https://qz.com/1022806/ethiopias-oromos-are-asserting-their-rights-for-addis-ababa-or-finfinne/

78. http://nazret.com/blog/index.php/2016/08/17/ethiopia-rise-of-the-amhara

79. http://bigthink.com/the-proverbial-skeptic/those-who-do-not-learn-history-doomed-to-repeat-it-really

80. https://en.m.wikipedia.org/wiki/Western_European_colonialism_and_colonization

81. Straus, Scott. 2006. The Order of Genocide: Race, Power, and War in Rwanda. Ithaca: Cornell University Press.

82. For comparison see Mart Bax . 1997. Mass Graves, Stagnating Identification, and Violence: A Case Study in the Local Sources of "the War" in Bosnia Hercegovina. Anthropological Quarterly 70 (1): 11-19.

83. One important finding by Straus (2000) on The Rwandan Genocide is pertinent here: "I found little evidence of widespread interpersonal ethnic hatred. On a series of indicators-interethnic personal relations, attitudes toward ethnic intermarriage, and family connections to Tutsis through intermarriage-the survey yielded consistent evidence among respondents of positive pre-genocide ethnic interaction. That said, many respondents spoke in categorical terms about "Hutus" and "Tutsis," in particular when discussing the very tense period after Habyarimana's assassination. Some respondents also repeated elements of the genocidal regime's propaganda, such as the idea that the rebels killed Hutu children and disemboweled pregnant women. On the other hand, certain commonly cited propaganda elements had limited resonance. For example, less than $10 \%$ of respondents had heard of-let alone respected—the infamous "Hutu Ten Commandments."(261)

84. Fearon, J.D. and Laitin, D.D. (2000) 'Violence and the Social Construction of Ethnic Identity', International Organization, 54(4), pp. 845-877. doi: 10.1162/002081800551398.

85. Arendt, Hannah, "Collective Responsibility." in Amor Mundi, ed. J.W. Brenner (Dordrecht: Martinus Nijhoff Publishers, (1987) p. 50.

86. Arendt, Hannah, "Collective Responsibility." in Amor Mundi, ed. J.W. Brenner (Dordrecht: Martinus Nijhoff Publishers, (1987) p. 50.

87. For a further analysis of the phenomenon see French, Peter A., ed., Individual and Collective Responsibility, (Cambridge, Mass: Schenkman, 1972). 
88. May, Larry, The Morality of Groups (Notre Dame: University of Notre Dame Press, 1987).

89. French, Peter A., ed., Individual and Collective Responsibility, (Cambridge, Mass: Schenkman, 1972) ; and also Arendt, Hannah, "Collective Responsibility." in Amor Mundi, ed. J.W. Brenner (Dordrecht: Martinus Nijhoff Publishers, (1987) p. 50.

90. Straus, Scott. 2006. The Order of Genocide: Race, Power, and War in Rwanda. Ithaca: Cornell University Press.

91. The Internet Encyclopedia of Philosophy (IEP) (ISSN 2161-0002) Retrieved Dec 302016 : http://www.iep.utm.edu/collecti/

92. Bowker, Gordon (2003). Inside George Orwell: A Biography. Palgrave Macmillan.

93. Orwell, George (1949). Nineteen Eighty-Four. A novel. New York: Harcourt, Brace \& Co. 